\title{
Structure-Activity Relationship of Piperine and its Synthetic Analogues for their Inhibitory Potentials of Rat Hepatic Microsomal Constitutive and Inducible Cytochrome P450 Activities
}

\author{
Surrinder Koul, ${ }^{\text {a }}$ Jawahir L. Koul, ${ }^{\text {a }}$ Subhash C. Taneja, ${ }^{\text {a }}$ Kanaya L. Dhar, ${ }^{\text {a }}$ \\ Deshvir S. Jamwal, ${ }^{\mathrm{b}}$ Kuldeep Singh, ${ }^{\mathrm{b}}$ Rashmeet K. Reen ${ }^{\mathrm{b}}$ and Jaswant Singh ${ }^{\mathrm{b}}$ ** \\ ${ }^{a}$ Natural Products Chemistry Division, Regional Research Laboratory (CSIR), Jammu-tawi 180001, India \\ ${ }^{\mathrm{b}}$ Biochemistry Laboratory, Division of Pharmacology, Regional Research Laboratory (CSIR), Jammu-tawi 180001, India
}

Received 16 July 1999; accepted 25 September 1999

\begin{abstract}
Inhibitors of drug metabolism have important implications in pharmaco-toxicology and agriculture. We have reported earlier that piperine, a major alkaloid of black and long peppers inhibits both constitutive and inducible cytochrome P450 (CYP)dependent drug metabolising enzymes. In the present study, an attempt has been made to prepare several novel synthetic analogues so as to relate various modifications in the parent molecule to the inhibition of CYP activities. Two types of mono-oxygenase reactions arylhydrocarbon hydroxylase $(\mathrm{AHH})$ and 7 -methoxycoumarin- $O$-demethylase (MOCD) have been studied. Inhibition studies were investigated in rat microsomal fraction prepared from untreated, 3MC- and PB- treated rat liver in vitro. Modifications were introduced into the piperine molecule: (i) in the phenyl nucleus, (ii) in the side chain and (iii) in the basic moiety. Thus, 38 compounds have been subjected to such studies, and simultaneously an attempt has also been made to arrive at the structureactivity relationship of synthetic analogues. In general, most of the inhibitory potential of the parent molecule is lost with modification in either of the three components of piperine. Saturation of the side chain resulted in significantly enhanced inhibition of CYP while modifications in the phenyl and basic moieties in few analogues offered maximal selectivity in inhibiting either constitutive or inducible CYP activities. Thus few novel analogues as CYP inactivators have been synthesized which may have important consequences in pharmacokinetics and bioavailability of drugs. (C) 2000 Elsevier Science Ltd. All rights reserved.
\end{abstract}

\section{Introduction}

Piperine (trans-trans-isomer of 1-piperoyl piperidine) is a major ingredient of piper species, Piper nigrum Linn and Piper longum Linn, which are commonly used as spices and in various traditional systems of medicines. ${ }^{1}$ Earlier studies from this laboratory have demonstrated that piperine inhibits several constitutive and inducible cytochrome P450 (CYP) activities in vitro and in vivo. ${ }^{2-7}$ We postulated that the use of piperine in the form of piper species in several traditional herbal formulations might have been responsible for the enhancement of

$\overline{\text { Keywords: }}$ piperine analogues; rat microsomes; cytochrome $\mathrm{P} 450$ inhibition; structure-activity relationship.

Abbreviations: AHH, arylhydrocarbon hydroxylase; BP, benzo(a)pyrene; CYP, cytochrome P450; MOC, 7-methoxycoumarin; MOCD, 7-methoxycoumarin- $O$-demethylase; 3MC, 3-methylcholanthrene; MDP, methylenedioxyphenyl; PB, phenobarbital.

*Corresponding author. Tel.: + 191-572002/579117/549084; fax:

+191-548607/546383; e-mail: rrlj@nde.vsnl.net.in drug bioavailability consequent to modulation of drug metabolism. ${ }^{2}$ Subsequently, it was shown to enhance the bioavailabilty of phenytoin in healthy volunteers, ${ }^{8}$ reduce aflatoxin $\mathrm{B} 1$ binding of $\mathrm{DNA}^{9}$ and protected hepatoma cells ${ }^{4}$ and V79 constructs of rat CYP2B $1^{10}$ in cultures from cytotoxicity and genotoxicity of $\mathrm{AFB}_{1}$ by impairing CYP mediated activation of the mycotoxin. Piperine also produced differential inhibition of glucuronidation in guinea pig enterocytes and rat liver, while conjugated double bonds appeared essential for in vitro inhibition of hepatic UDP-glucose dehydrogenase ${ }^{6}$ irrespective of the oxidation state of piperidine or methylenedioxyphenyl (MDP) rings. Piperine, thus, appears pharmacologically an important molecule despite the fact that it is a natural compound of very low toxicological consequences ${ }^{11}$ and has been in use the world over for the palatability of food in the form of black pepper. At least four major metabolites of piperine from human urine have been reported, viz. 5-(3,4dihydroxy phenyl)-2,4-pentadienoic acid piperidide and its 4-hydroxy-piperidine analogues and their respective 
tetrahydro-analogues ${ }^{12}$ without any studies of their effect on drug metabolism. We became primarily interested to know whether or not any structural modifications in the parent molecule piperine would result in differential inhibition of rat hepatic constitutive and inducible CYP activities. In addition, such studies might also prove useful in developing specific inactivators of certain CYPs from natural lead bioactive molecules such as piperine.

A number of distinct CYPs are present in normal hepatic and extrahepatic tissues whose relative population may be altered due to the in vivo exposure to drugs and chemicals. For instance, 3-methylcholanthrene (3MC) induces members of CYP1A family and phenobarbital (PB) induces several members of CYP2 and CYP3 families. ${ }^{13}$ Accordingly, the disposition of drugs and CYP substrates would proceed along pathways different from normal tissues. Therefore, the inhibition or induction of drug metabolising enzymes has important consequences on the pharmacokinetics of drugs and hence their bioavailability. For that matter, a large number of inhibitors of CYP have reportedly been evaluated for the management of breast or uterine cancer, inflammation and other diseases. ${ }^{13-15}$ In this concern use of aromatase inhibitors ${ }^{16}$ and development of synergists as inhibitors of CYPs have already shown their due benefits. Moreover, in clinical therapeutics, the treatment regimens ought to be changed because of the inducibility of particular CYPs towards a drug substrate (s). It is, therefore, desirable to search for potential CYP inhibitors with maximal isoenzymic selectivity which indeed appears extremly difficult in view of the diversity and overlapping substrate specificity of various CYP isoforms.

Piperine structure (Fig. 1) consists of three important components, viz. methylenedioxyphenyl (MDP) ring, side chain with conjugated double bonds and a basic piperidine moiety attached through a carbonylamide linkage to side chain. Each of these moieties might influence the constitutive and inducibility characteristics of various CYPs. Furthermore, an MDP ring appears to be a common functional group of several naturally occuring compounds of pharmacological importance ${ }^{17}$ contributing significantly to modulate drug metabolism. ${ }^{18}$ The natural alkaloid consumed world-wide produces differential inhibition of CYPs., ${ }^{2,19}$ When compared to another MDP-containing insecticide synergist piperonyl butoxide, the latter produced a strong biphasic effect, an initial inhibition followed by induction. ${ }^{19}$ Though piperine also induced the CYP1A1 activity by transcription activation, the overall inhibition of benzo(a)pyrene metabolism and AHH activity

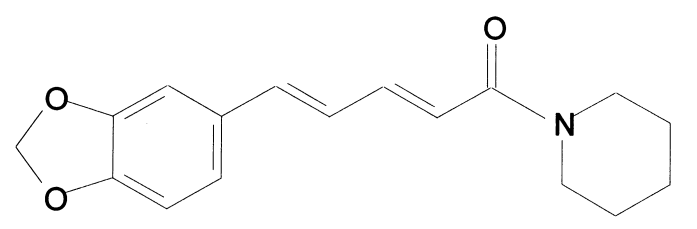

Figure 1. Structure of piperine. appeared to be the consequence of direct interaction of piperine with CYP1A1 gene product. ${ }^{7}$ Thus apparent shortcomings, if any, in piperine molecule could perhaps be overcome by introducing various structural modifications in the molecule.

In this study we, therefore, have introduced several modifications in piperine so as to correlate its structure to the inhibition of constitutive and inducible rat hepatic CYP activities. For this purpose microsomes from untreated-, 3MC and PB -treated rat liver and two types of diagnostic substrates benzo(a)pyrene and 7-methoxycoumarin have been used. Piperine earlier was reported to inhibit atleast two CYP-dependent marker reactions, viz. arylhydrocarbon (benzo(a)pyrene) hydroxylase (AHH) and 7-methoxycoumarin $O$-demethylase (MOCD) in H4IIEC 3 cells. ${ }^{4}$ The former reaction primarily is mediated by members of CYP family which are inducible by polycyclic aromatic hydrocarbons, i.e. CYP1A. ${ }^{20}$ The latter is catalyzed by constitutive, phenobarbital or dexamethasone inducible CYP forms. ${ }^{21}$ Further, MOCD activity was observed in preparations of SD1 cells containing only CYP2B1, the major PBinducible CYP of rat liver and not in XEM1 cells containing only CYP1A $1 .{ }^{21}$ It may be mentioned that dexamethasone and PB- inducible CYPs involve several members of CYP2 and CYP3 families. Measurement of the activities of AHH and MOCD assayed in the present study offer a simple system of choice for in vitro screening of a large number of synthetic analogues of piperine as CYP inhibitors in contrast to the measurement of hexobarbital induced sleeping time in intact animals. $^{22}$ In this study we, therefore, report the synthesis of several piperine analogues (Table 1) and attempted to correlate their structures with the inhibition of constitutive and inducible CYP activities. The study may be found very useful in developing new analogues as selective inactivators of CYPs.

\section{Results}

\section{Structure-activity relationship of substituted phenylpentadienoic acid derivatives with the inhibition of hepatic microsomal monooxygenase activitities in vitro}

The specific activities of $\mathrm{AHH}$ and MOCD in microsomes from untreated, 3MC- and PB-treated rat liver, and the effect of piperine thereon are given in Table 2. These values are taken as controls for comparing the CYP activities of corresponding microsomes under the influence of various piperine analogues. Piperine as such produced concentration-dependent and equipotent inhibition of both constitutive and inducible AHH and MOCD activities. Similarly, the influence of various piperine analogues on the CYP activities of liver microsomes from untreated, 3MC- and PB- treated rats was investigated in vitro at three different concentrations of 10, 30 and $100 \mu \mathrm{M}$ (Tables 3 and 4). The monooxygenases inhibitory potential of each compound was compared with the parent molecule piperine by evaluating the $\mathrm{IC}_{50}$ values, the concentration which brings about $50 \%$ of enzymatic inhibition. 
Table 1.

\begin{tabular}{|c|c|c|c|c|c|c|c|}
\hline Compound & Structure & MF & $\mathrm{Mp}\left({ }^{\circ} \mathrm{C}\right)$ & Compound & Structure & MF & $\operatorname{Mp}\left({ }^{\circ} \mathrm{C}\right)$ \\
\hline 8 & o & $\mathrm{C}_{17} \mathrm{H}_{21} \mathrm{NO}_{2}$ & 135 & 23 & & $\mathrm{C}_{17} \mathrm{H}_{19} \mathrm{NO}_{3}$ & 113 \\
\hline 9 & & $\mathrm{C}_{16} \mathrm{H}_{19} \mathrm{NO}_{2}$ & 137 & 24 & & $\mathrm{C}_{24} \mathrm{H}_{27} \mathrm{NO}_{3}$ & 116 \\
\hline 10 & & $\mathrm{C}_{17} \mathrm{H}_{22} \mathrm{~N}_{2} \mathrm{O}_{2}$ & 201 & 25 & & $\mathrm{C}_{23} \mathrm{H}_{25} \mathrm{NO}_{3}$ & 155 \\
\hline 11 & 0 & $\mathrm{C}_{17} \mathrm{H}_{26} \mathrm{~N}_{2} \mathrm{O}_{2}$ & 183 & 26 & & $\mathrm{C}_{23} \mathrm{H}_{27} \mathrm{NO}_{3}$ & 183 \\
\hline 12 & & $\mathrm{C}_{16} \mathrm{H}_{17} \mathrm{NO}_{3}$ & 147 & & DMe & & \\
\hline & & & & 27 & & $\mathrm{C}_{19} \mathrm{H}_{25} \mathrm{NO}_{4}$ & 214 \\
\hline 13 & & $\mathrm{C}_{16} \mathrm{H}_{19} \mathrm{NO}_{3}$ & 144 & & OMe & & \\
\hline & & & a & 28 & & $\mathrm{C}_{18} \mathrm{H}_{23} \mathrm{NO}_{4}$ & 190 \\
\hline 15 & & $\mathrm{C}_{16} \mathrm{H}_{21} \mathrm{NO}_{3}$ & a & 29 & & $\mathrm{C}_{21} \mathrm{H}_{27} \mathrm{NO}_{2}$ & 164 \\
\hline 16 & & $\mathrm{C}_{16} \mathrm{H}_{23} \mathrm{NO}_{3}$ & a & 30 & & $\mathrm{C}_{20} \mathrm{H}_{25} \mathrm{NO}_{2}$ & 117 \\
\hline 17 & & $\mathrm{C}_{16} \mathrm{H}_{23} \mathrm{NO}_{3}$ & a & 31 & 0 & $\mathrm{C}_{21} \mathrm{H}_{29} \mathrm{NO}_{2}$ & 137 \\
\hline 18 & & $\mathrm{C}_{18} \mathrm{H}_{23} \mathrm{NO}_{3}$ & 118 & 32 & 0 & $\mathrm{C}_{15} \mathrm{H}_{17} \mathrm{NO}_{3}$ & 89 \\
\hline 19 & & $\mathrm{C}_{17} \mathrm{H}_{21} \mathrm{NO}_{3}$ & 148 & 33 & & $\mathrm{C}_{14} \mathrm{H}_{15} \mathrm{NO}_{3}$ & 146 \\
\hline & & & & 34 & 0 & $\mathrm{C}_{19} \mathrm{H}_{25} \mathrm{NO}_{2}$ & 122 \\
\hline 20 & 0 & $\mathrm{C}_{17} \mathrm{H}_{23} \mathrm{NO}_{3}$ & 114 & & & & \\
\hline & & & & 35 & & $\mathrm{C}_{17} \mathrm{H}_{23} \mathrm{NO}_{2}$ & 89 \\
\hline 21 & 0 & $\mathrm{C}_{19} \mathrm{H}_{27} \mathrm{NO}_{3}$ & 148 & & & & \\
\hline & & & & 36 & & $\mathrm{C}_{18} \mathrm{H}_{25} \mathrm{NO}_{2}$ & 86 \\
\hline 22 & & $\mathrm{C}_{18} \mathrm{H}_{21} \mathrm{NO}_{3}$ & 162 & 37 & & $\mathrm{C}_{20} \mathrm{H}_{29} \mathrm{NO}_{2}$ & 71 \\
\hline
\end{tabular}


Table 2. Influence of piperine on hepatic microsomal $\mathrm{AHH}$ and MOCD activities of untreated and inducers - pretreated rats ${ }^{\mathrm{a}}$

\begin{tabular}{lrcccc}
\hline & \multicolumn{2}{c}{ Monooxygenase activities $(\mathrm{pmol} / \mathrm{min} / \mathrm{mg}$ protein) } \\
\cline { 2 - 3 } & \multicolumn{2}{c}{ AHH } & & \multicolumn{2}{c}{ MOCD } \\
\cline { 2 - 3 } \cline { 5 - 6 } Compound & Untreated & 3MC-inducible & & Untreated & PB-inducible \\
\hline Control & $57 \pm 7$ & $530 \pm 47$ & & $388 \pm 25$ & $1048 \pm 81$ \\
Piperine $(\mu \mathrm{M}):$ & & & & \\
$\mathbf{1 0}$ & $46.7 \pm 5.1$ & $439 \pm 50$ & & $310 \pm 23$ & $880 \pm 65$ \\
$\mathbf{3 0}$ & $29.1 \pm 3.2$ & $312 \pm 40$ & & $241 \pm 27$ & $618 \pm 46$ \\
$\mathbf{1 0 0}$ & $17 \pm 2.5$ & $138 \pm 14$ & & $128 \pm 11$ & $419 \pm 44$ \\
\hline
\end{tabular}

The data are mean values $\pm \mathrm{SD}(n=8)$ from rat liver microsomal preparations. These enzyme activities were used as controls for comparison of inhibitory efficacy of the above monooxygenases by various synthetic analogues shown in Tables 3 and 4. Conditions for preparation of microsomes and enzyme assays are given in Materials and Methods. $P>0.01$ (Student's ' $t$ ' test).

(i) Influence of substituted derivatives of phenylpentadienoic acid on microsomal constitutive and $3 \mathrm{MC}$-inducible AHH activity of rat liver in vitro. Piperine elicited a strong concentration related inhibition of both constitutive and inducible AHH activities (Tables 3). All the three structural components in the piperine molecule appeared obligatory for inhibition of both constitutive and inducible AHH activities (Table 3). (a) Influence of modifications of the basic moiety on AHH activity. Presence of piperidine moiety in piperine offered an appropriate combination for inhibiting both the constitutive and the $3 \mathrm{MC}$ - inducible $\mathrm{AHH}$ activities. Replacement of piperidine moiety by pyrrolidine or $n$ butyl amines (12 and 13) rendered the inducible $\mathrm{AHH}$ activitity insensitive to these analogues while the constitutive one was inhibited poorly.

(b) Influence of modifications in aromatic ring on $\mathrm{AHH}$ activity. Replacement of the MDP ring by either ethylenedioxyphenyl, 3-methoxy-4-benzyloxyphenyl, 4-methoxyphenyl, 3,4-dimethoxyphenyl, 3,4,5-trimethoxyphenyl and 2,2-dimethyl-3,4-dihydrobenzopyran produced compounds $(\mathbf{8}, \mathbf{1 8}, \mathbf{2 2}, \mathbf{2 4}, 27$ and 29) which in general did not influence the inducible AHH while the constitutive one exhibited poor sensitivity compared to strong inhibition elicited by piperine. The inhibitory effect in general was remarkably reduced from null effect in the inducible form to a moderate inhibition in the constitutive enzyme. The studies suggested that various compounds synthesised by modifying the phenyl ring without disturbing the side chain and the basic moiety again had no influence on the inducibile $\mathrm{AHH}$ activity. Furthermore, this effect again was found to be comparable with compounds having modifications in both the phenyl and the basic moieties $(\mathbf{9}, \mathbf{1 9}, \mathbf{2 0}, \mathbf{2 3}, \mathbf{2 6}$, 28, 30 and 31). An exception was found with analogue

Table 3. Comparative influence of piperine and its synthetic analogues on the constitutive and $3 \mathrm{MC}$-inducible rat hepatic microsomal AHH activity in vitro ${ }^{\text {a }}$

\begin{tabular}{|c|c|c|c|c|c|c|c|c|}
\hline \multirow[b]{3}{*}{ Compounds } & \multicolumn{8}{|c|}{ AHH activity (pmol 3-OH-BP formed per min per mg protein) } \\
\hline & \multicolumn{3}{|c|}{ Untreated } & \multicolumn{4}{|c|}{ 3MC-inducible } & \multirow[b]{2}{*}{$\mathrm{IC}_{50}$} \\
\hline & $10 \mu \mathrm{M}$ & $30 \mu \mathrm{M}$ & $100 \mu \mathrm{M}$ & $\mathrm{IC}_{50}$ & $10 \mu \mathrm{M}$ & $30 \mu \mathrm{M}$ & $100 \mu \mathrm{M}$ & \\
\hline $\begin{array}{l}\text { Piperine } \\
\text { Analogues }\end{array}$ & $46.7 \pm 5.1$ & $29.1 \pm 3.2$ & $17.1 \pm 1.5$ & 35 & $439 \pm 50$ & $312 \pm 40$ & $138 \pm 14$ & 45 \\
\hline 12 & $53.5 \pm 4.8$ & $37.6 \pm 3.5$ & $34.5 \pm 3.5$ & 80 & $525 \pm 50$ & $549 \pm 34$ & $548 \pm 25$ & $\mathrm{NI}^{\mathrm{b}}$ \\
\hline 13 & $59.8 \pm 6.0$ & $40.5 \pm 3.9$ & $33.1 \pm 4.1$ & 105 & $581 \pm 32$ & $653 \pm 47$ & $617 \pm 51$ & NI \\
\hline 22 & $51.9 \pm 6.8$ & $50.2 \pm 4.9$ & $43.9 \pm 5.1$ & $>100$ & $464 \pm 37$ & $418 \pm 55$ & $444 \pm 48$ & NI \\
\hline 23 & $54.1 \pm 5.6$ & $53.0 \pm 6.0$ & $47.3 \pm 4.1$ & NI & $510 \pm 37$ & $490 \pm 40$ & $474 \pm 44$ & NI \\
\hline 24 & $52.5 \pm 4.5$ & $30.3 \pm 3.5$ & $28.6 \pm 7.5$ & 100 & $500 \pm 30$ & $513 \pm 35$ & $520 \pm 36$ & NI \\
\hline 25 & $49.0 \pm 3.7$ & $28.8 \pm 4.5$ & $21.7 \pm 1.9$ & 35 & $505 \pm 67$ & $551 \pm 59$ & $525 \pm 61$ & NI \\
\hline 26 & $55.9 \pm 4.7$ & $48.5 \pm 5.9$ & $34.8 \pm 4.2$ & $>100$ & $495 \pm 61$ & $576 \pm 53$ & $525 \pm 48$ & NI \\
\hline 8 & $53.6 \pm 3.9$ & $46.3 \pm 3.5$ & $32.4 \pm 2.5$ & $>100$ & $521 \pm 56$ & $510 \pm 42$ & $490 \pm 30$ & NI \\
\hline 9 & $55 \pm 5.0$ & $49.0 \pm 3.9$ & $43.8 \pm 4.8$ & NI & $503 \pm 47$ & $508 \pm 42$ & $511 \pm 50$ & NI \\
\hline 10 & $57 \pm 4.8$ & $51.9 \pm 4.4$ & $38.2 \pm 4.1$ & $>100$ & $525 \pm 71$ & $540 \pm 47$ & $500 \pm 37$ & NI \\
\hline 18 & $57.6 \pm 3.0$ & $48.5 \pm 5.1$ & $39.9 \pm 2.1$ & $\mathrm{NI}$ & $490 \pm 39$ & $474 \pm 27$ & $413 \pm 43$ & NI \\
\hline 19 & $53.0 \pm 4.5$ & $57.0 \pm 4.1$ & $53.0 \pm 2.5$ & NI & $459 \pm 51$ & $444 \pm 38$ & $464 \pm 25$ & NI \\
\hline 20 & $54.2 \pm 6.9$ & $49.1 \pm 6.7$ & $41.1 \pm 3.1$ & NI & $495 \pm 46$ & $510 \pm 35$ & $511 \pm 21$ & NI \\
\hline 27 & $53 \pm 3.7$ & $54.2 \pm 5.1$ & $41.1 \pm 5.9$ & $>100$ & $454 \pm 61$ & $510 \pm 47$ & $505 \pm 48$ & NI \\
\hline 28 & $48.5 \pm 6.8$ & $43.9 \pm 5.6$ & $37.1 \pm 4.2$ & $>100$ & $484 \pm 51$ & $459 \pm 60$ & $459 \pm 49$ & NI \\
\hline 29 & $54.7 \pm 4.6$ & $45.0 \pm 3.4$ & $30.8 \pm 4.6$ & 105 & $444 \pm 29$ & $479 \pm 50$ & $490 \pm 45$ & NI \\
\hline 30 & $51.3 \pm 3.1$ & $41.6 \pm 2.9$ & $35.9 \pm 4.7$ & $>100$ & $485 \pm 34$ & $479 \pm 37$ & $515 \pm 42$ & NI \\
\hline 31 & $47.3 \pm 4.0$ & $34.2 \pm 2.9$ & $28.5 \pm 3.0$ & 100 & $459 \pm 45$ & $408 \pm 39$ & $357 \pm 31$ & $>100$ \\
\hline 32 & $55.9 \pm 4.0$ & $42.8 \pm 4.1$ & $30.2 \pm 4.2$ & $>100$ & $525 \pm 45$ & $291 \pm 21$ & $133 \pm 11$ & 40 \\
\hline 33 & $53.6 \pm 6.8$ & $50.7 \pm 5.9$ & $31.9 \pm 4.1$ & $>100$ & $459 \pm 36$ & $270 \pm 19$ & $127 \pm 16$ & 35 \\
\hline 34 & $53.6 \pm 4.9$ & $48.5 \pm 4.2$ & $35.9 \pm 4.0$ & $>100$ & $490 \pm 51$ & $464 \pm 49$ & $479 \pm 45$ & NI \\
\hline 14 & $49.6 \pm 3.4$ & $18.2 \pm 2.4$ & $7.41 \pm 0.4$ & 23 & $492 \pm 54$ & $540 \pm 45$ & $490 \pm 39$ & NI \\
\hline 15 & $46.2 \pm 3.9$ & $34.7 \pm 3.1$ & $25.9 \pm 3.4$ & 70 & $469 \pm 45$ & $464 \pm 51$ & $479 \pm 48$ & NI \\
\hline 16 & $46.7 \pm 3.9$ & $34.2 \pm 2.7$ & $18.8 \pm 1.1$ & 50 & $474 \pm 40$ & $449 \pm 50$ & $469 \pm 47$ & NI \\
\hline 17 & $48.4 \pm 4.9$ & $29.1 \pm 3.0$ & $10.3 \pm 0.9$ & 32 & $505 \pm 39$ & $439 \pm 39$ & $428 \pm 27$ & NI \\
\hline
\end{tabular}

aTest compounds were dissolved in $50 \%$ methanol and introduced in $10 \mu \mathrm{L}$ of the vehicle in $1 \mathrm{~mL}$ of the assay system before initiation of the reaction with the substrate. Controls received the vehicle only. Assays were performed in duplicate and data are mean \pm SD of three experiments. Specific activities of untreated controls are given in Table 2.

${ }^{\mathrm{b}} \mathrm{NI}=$ no inhibition. 
Table 4. Comparative influence of piperine and its synthetic analogues on the constitutive and PB-inducible rat hepatic microsomal 7-methoxycoumarin $O$-demethylase activity in vitro ${ }^{a}$

\begin{tabular}{|c|c|c|c|c|c|c|c|c|}
\hline \multirow[b]{3}{*}{ Compounds } & \multicolumn{8}{|c|}{ MOCD activity (pmol 7-hydroxycoumarin formed $/ \mathrm{min} / \mathrm{mg}$ protein) } \\
\hline & \multicolumn{3}{|c|}{ Untreated } & \multirow[b]{2}{*}{$\mathrm{IC}_{50}$} & \multicolumn{3}{|c|}{ PB-inducible } & \multirow[b]{2}{*}{$\mathrm{IC}_{50}$} \\
\hline & $10 \mu \mathrm{M}$ & $30 \mu \mathrm{M}$ & $100 \mu \mathrm{M}$ & & $10 \mu \mathrm{M}$ & $30 \mu \mathrm{M}$ & $100 \mu \mathrm{M}$ & \\
\hline $\begin{array}{l}\text { Piperine } \\
\text { Analogues }\end{array}$ & $310 \pm 23$ & $241 \pm 27$ & $128 \pm 11$ & 45 & $880 \pm 65$ & $618 \pm 46$ & $419 \pm 44$ & 47 \\
\hline 12 & $335 \pm 30$ & $339 \pm 26$ & $312 \pm 22$ & 100 & $1032 \pm 72$ & $922 \pm 80$ & $728 \pm 46$ & 90 \\
\hline 13 & $314 \pm 24$ & $353 \pm 31$ & $427 \pm 37$ & NI & $1100 \pm 98$ & $1048 \pm 87$ & $964 \pm 100$ & NI \\
\hline 22 & $415 \pm 49$ & $376 \pm 30$ & $144 \pm 15$ & 80 & $954 \pm 79$ & $828 \pm 80$ & $545 \pm 45$ & 100 \\
\hline 23 & $314 \pm 23$ & $303 \pm 32$ & $229 \pm 23$ & $>100$ & $713 \pm 62$ & $482 \pm 45$ & $367 \pm 41$ & 25 \\
\hline 24 & $367 \pm 42$ & $326 \pm 50$ & $240 \pm 35$ & $>100$ & $938 \pm 80$ & $838 \pm 76$ & $645 \pm 56$ & $>100$ \\
\hline 25 & $400 \pm 34$ & $349 \pm 30$ & $244 \pm 19$ & $>100$ & $891 \pm 70$ & $796 \pm 68$ & $660 \pm 56$ & $>100$ \\
\hline 26 & $334 \pm 34$ & $353 \pm 25$ & $244 \pm 18$ & $>100$ & $985 \pm 89$ & $681 \pm 68$ & $639 \pm 56$ & $>100$ \\
\hline 8 & $380 \pm 37$ & $320 \pm 31$ & $278 \pm 25$ & $>100$ & $991 \pm 68$ & $680 \pm 62$ & $550 \pm 44$ & 90 \\
\hline 9 & $388 \pm 31$ & $331 \pm 52$ & $321 \pm 37$ & $\mathrm{NI}^{\mathrm{b}}$ & $\mathrm{ND}^{\mathrm{c}}$ & ND & ND & \\
\hline 18 & $322 \pm 27$ & $291 \pm 23$ & $213 \pm 20$ & $>100$ & $1017 \pm 97$ & $744 \pm 62$ & $440 \pm 26$ & 70 \\
\hline 19 & $361 \pm 23$ & $272 \pm 22$ & $233 \pm 19$ & $>100$ & $1048 \pm 79$ & $880 \pm 71$ & $629 \pm 80$ & $>100$ \\
\hline 20 & $376 \pm 40$ & $323 \pm 29$ & $241 \pm 24$ & $>100$ & $765 \pm 67$ & $514 \pm 45$ & $356 \pm 32$ & 28 \\
\hline 27 & $353 \pm 37$ & $314 \pm 29$ & $225 \pm 20$ & $>100$ & $775 \pm 63$ & $681 \pm 59$ & $513 \pm 48$ & 90 \\
\hline 28 & $361 \pm 26$ & $337 \pm 27$ & $229 \pm 21$ & $>100$ & $911 \pm 99$ & $796 \pm 59$ & $629 \pm 42$ & $>100$ \\
\hline 29 & $361 \pm 48$ & $295 \pm 25$ & $140 \pm 17$ & 65 & $796 \pm 67$ & $597 \pm 53$ & $338 \pm 21$ & 40 \\
\hline 30 & $376 \pm 26$ & $334 \pm 30$ & $198 \pm 14$ & $>100$ & $859 \pm 81$ & $451 \pm 36$ & $335 \pm 27$ & 27 \\
\hline 31 & $369 \pm 41$ & $349 \pm 33$ & $353 \pm 29$ & NI & $943 \pm 78$ & $954 \pm 69$ & $838 \pm 81$ & NI \\
\hline 32 & $369 \pm 18$ & $334 \pm 34$ & $256 \pm 26$ & $>100$ & $1037 \pm 51$ & $890 \pm 46$ & $713 \pm 37$ & $>100$ \\
\hline 33 & $330 \pm 31$ & $302 \pm 19$ & $244 \pm 12$ & $>100$ & $1079 \pm 90$ & $943 \pm 72$ & $744 \pm 45$ & $>100$ \\
\hline 34 & $450 \pm 40$ & $318 \pm 27$ & $202 \pm 18$ & 100 & $870 \pm 43$ & $702 \pm 50$ & $325 \pm 39$ & 50 \\
\hline 14 & $303 \pm 21$ & $132 \pm 12$ & $109 \pm 11$ & 25 & $796 \pm 68$ & $503 \pm 41$ & $367 \pm 33$ & 27 \\
\hline 15 & $357 \pm 49$ & $326 \pm 29$ & $198 \pm 20$ & 100 & $964 \pm 90$ & $796 \pm 77$ & $492 \pm 50$ & 85 \\
\hline 16 & $341 \pm 31$ & $124 \pm 16$ & $97 \pm 11$ & 23 & $1048 \pm 89$ & $681 \pm 43$ & $352 \pm 37$ & 50 \\
\hline 17 & $392 \pm 40$ & $204 \pm 21$ & $115 \pm 16$ & 39 & $954 \pm 81$ & $618 \pm 56$ & $272 \pm 29$ & 45 \\
\hline
\end{tabular}

a Specific activities of untreated controls are given in Table 2. Other conditions were the same as described in Table 3.

bNI, no inhibition.

${ }^{\mathrm{c}} \mathrm{ND}$, not determined.

25 where replacement of MDP by 3-methoxy-4-benzyloxyphenyl and piperidine by pyrrolidine resulted in inhibition of only constitutive activity which was comparable to piperine.

(c) Influence of modifications of the side chain on AHH activity. Having modified the two terminals of the piperine molecule, we focused our attention on the central olefinic part of the molecule. Two types of major modifications were introduced in this case, e.g. removal of one double bond, (32) and saturation of the conjugated double bonds (14). These modifications, without any change in other parts of the parent molecule, offered interesting features. Removal of a double bond (32) resulted into marked loss of inhibitory effect on constitutive AHH while it retained its inhibitory effect on the inducible AHH almost equipotent to piperine. A similar effect was observed when the basic moiety of this molecule was replaced by pyrrolidine moiety (33). On the contrary, modification of MDP to benzopyranyl in 32, i.e. 34 resulted in complete abolition of both the constitutive and inducible AHH.

Therefore, presence of conjugated double bonds in piperine appeared essential for overall inhibition of CYP activities and the level of saturation may tilt the balance of inhibition singularly either to constitutive or inducible forms of CYPs. For instance, saturation of double bonds of piperine (14) rendered it ineffective towards 3MC-inducible form of CYP while it elicited pronounced inhibition of constitutive AHH activity. The potentiation of this inhibition of constitutive activity was almost higher by 2-fold compared to piperine. Further, it is important to note that modification of basic moiety in 14 resulted into compounds $(\mathbf{1 5}, \mathbf{1 6}, \mathbf{1 7})$ having similar or less inhibitory effect as that of piperine on the constitutive $\mathrm{AHH}$ while such modifications in the parent molecule have rendered them almost ineffective $(\mathbf{1 2}, \mathbf{1 3})$.

Besides the above mentioned compounds, we also synthesised some other analogues of piperine, viz. 11, 21 and $\mathbf{3 7}$, where modifications were introduced in all the three parts of the molecules. Such compounds did not show any differential or specific inhibitory effects against enzyme activities assayed (not shown).

(ii) Influence of substituted derivatives of phenylpentadienoic acid on microsomal constitutive and PB-inducible MOCD activity of rat liver in vitro. Like AHH activity, modifications introduced in the piperine molecule also affected both the constitutive and PB-inducible MOCD activities (Table 4).

(a) Influence of modifications of the basic moiety on MOCD activity. Replacement of piperidine in piperine by pyrrolidine and $n$-butylamine (12 and 13) had no influence on the constitutive with inducible MOCD activities, unlike the strong inhibition produced by piperine. We also observed a similar effect on $\mathrm{AHH}$ activity discussed above. 
(b) Influence of the modifications in the aromatic ring on MOCD activity. Modification of the MDP ring almost abolished the inhibitory influence on both the constitutive and inducible MOCD activities. For instance, replacement of MDP by either ethylenedioxyphenyl, 3methoxy-4-benzyloxyphenyl, 4-methoxyphenyl, 3,4-dimethoxyphenyl, 3,4,5-trimethoxyphenyl, and 2,2-dimethyl-3,4-dihydrobenzopyran produced compounds $(\mathbf{8}, \mathbf{1 8}, 22,24,27$ and 29) which in general did not influence the PB-inducible MOCD activity while the constitutive one exhibited poor sensitivity with an exception of $\mathbf{2 9}$ which was sensitive to induced activity as much as piperine. Further, when both the MDP and piperidine moieties were modified $(\mathbf{9}, \mathbf{1 9}, \mathbf{2 0}, \mathbf{2 3}, \mathbf{2 5}, \mathbf{2 6}$, 28, 30 and 31), most of the compounds lost their inhibitory potentials towards both constitutive and inducible MOCD with the exception of 20, 23 and 30 which exhibited pronounced inhibitory effect only on inducible MOCD where the $\mathrm{IC}_{50}$ values were half of piperine.

(c) Influence of modifications of the side chain on MOCD activity. Decrease in length of the side chain of piperine (removal of one double bond) without altering the MDP or the basic moiety formed compound (32) which had no influence on both the constitutive and inducible MOCD activities. This compound otherwise inhibited specifically the inducible AHH activity (see Table 3). A modification of the basic moiety in $\mathbf{3 2}$ lead to $\mathbf{3 3}$ having similar effects as $\mathbf{3 2}$. However, a modification in the MDP of $\mathbf{3 2}$ resulted in $\mathbf{3 4}$ which is capable of inhibiting PB-inducible MOCD as much as piperine but has no effect on the constitutive one. Such modifications are likely to yield more compounds which might impart differential specificity to the PB-inducible CYPs.

It is again interesting to note that saturation of double bonds of piperine, i.e. 14 leads to potentiation of the inhibition of both the constitutive and inducible MOCD activities as observed with AHH activity. However, replacement of basic moiety in $\mathbf{1 4}$ by pyrrolidine (15) resulted into a complete loss of inhibitory potential while its replacement by $n$-butylamide (16) elicited relatively stronger inhibition of only constitutive activity while replacement by $N, N$-diethylamide (17) exhibited sensitivity almost comparable to piperine. Other analogues of piperine, where modifications were introduced in all the three parts of the molecules $(\mathbf{1 1}, 21$ and 37) had no influence on MOCD activity as has been observed earlier at least against $\mathrm{AHH}$ activity (not shown).

\section{Influence of piperine analogues 14, 16 and 17 on the constitutive and inducible $\mathrm{AHH}$ and MOCD activities of the H4IIEC3/G- hepatoma cells in culture}

To investigate the initial interaction of these analogues with the mono-oxygenase activities, the cell cultures were exposed to the above compounds for $4 \mathrm{~h}$. Piperine mediated inhibition intensity of the monooxygenase activities in the hepatoma cells in culture was compared with three tetrahydropiperine derivatives (Table 5). Like in vitro inhibition of constitutive $\mathrm{AHH}$, these compounds elicited inhibition stronger than piperine in cell cultures while the BA-inducible activity in comparison
Table 5. Influence of piperine analogues on monooxygenase activities of hepatoma H4IIEC $3 / \mathrm{G}-$ cells in culture ${ }^{\mathrm{a}, \mathrm{c}}$

\begin{tabular}{lccccc}
\hline & \multicolumn{3}{c}{ Enzyme activity (pmol/min/mg protien) } \\
\cline { 2 - 3 } & \multicolumn{2}{c}{$\begin{array}{c}\text { Arylhydrocarbon } \\
\text { hydroxylase }\end{array}$} & & 7-Methoxycoumarindemethylase \\
\cline { 2 - 3 } \cline { 5 - 6 } Compound & Control & BA-treated & & Control & PB-treated \\
\hline DMSO & $68.4 \pm 2.3$ & $75 \pm 4$ & & $16.5 \pm 1.5$ & $13.5 \pm 3.0$ \\
Piperine & $6.4 \pm 2.3$ & $60 \pm 5$ & & $13.0 \pm 1.7$ & $8.5 \pm 1.0$ \\
$\mathbf{1 4}$ & $2.8 \pm 1.0$ & $63 \pm 6$ & & $7.0 \pm 0.1$ & $7.5 \pm 1.5$ \\
$\mathbf{1 6}$ & $5.3 \pm 0.8$ & $70 \pm 10$ & & $10.0 \pm 1.5$ & $12 \pm 1.0$ \\
$\mathbf{1 7}$ & $3.6 \pm 0.1$ & ND $^{\mathrm{b}}$ & & $8.0 \pm 0.5$ & $9.5 \pm 2.0$ \\
\hline
\end{tabular}

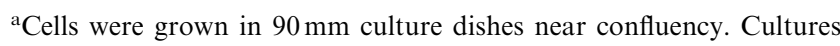
were incubated with medium containing $50 \mu \mathrm{M}$ of piperine analogues for $4 \mathrm{~h}$. In case of pretreatment of cultures to BA $(20 \mu \mathrm{M}, 18 \mathrm{~h})$ or PB ( $2 \mathrm{mM}, 3$ days), the experimental protocols were staggered so that the treatment with the above compounds started at the same time. Other conditions were the same as described in Materials and Methods.

${ }^{b} \mathrm{ND}$, not determined.

${ }^{\mathrm{c}}$ Data are mean $\pm \mathrm{SD}$ from three culture plates.

was not affected significantly. These compounds, nevertheless appeared equipotent in the inhibition of MOCD activity from untreated and PB-treated cultures. These results correlated well with the in vitro microsomal inhibition of mono-oxygenases by piperine. Further, long-term influence of these analogues on the inhibition or induction of $\mathrm{AHH}$ and MOCD has been investigated in cell cultures. Cell cultures were exposed to the medium containing $60 \mu \mathrm{M}$ analogues for $27 \mathrm{~h}$ (Fig. 2). Both piperine and $\mathbf{1 4}$ induced $\mathrm{AHH}$ activity by about $70 \%$ while the inducibility was of low magnitude with 16 and 17. However, MOCD continued exhibiting marginal impairment even after $27 \mathrm{~h}$ of exposure with these analogues while the magnitude of inhibition remained relatively higher with $\mathbf{1 6}$ and $\mathbf{1 7}$ compared to piperine.

\section{Influence of piperine analogues on hexobarbital induced sleeping time in mice}

Intraperitoneal administration of the above selected compounds viz. 14, 16 and 17 potentiated hexobarbitalinduced sleeping time over piperine (Fig. 3).

\section{Comparative effect of piperine analogues on the kinetics of MOC demethylation by rat liver microsomes in vitro}

Microsomes from untreated rat liver were used. Kinetics of enzyme inhibition in the presence and absence of piperine and two selected analogues using LineweaverBurk double reciprocal plot and Dixon plot of analysis has been determined. The values of the kinetic data are given in Table 6. All the three analogues caused non-competitive inhibition. The $V_{\max }$ decreased with increasing inhibitor concentrations while the apparent $K_{\mathrm{m}}$ of $151 \mu \mathrm{M}$ was almost similar when dealkylation of MOC was studied in the presence and absence of piperine and its analogues. The values of half-maximal $K_{\mathrm{i}}$ of enzyme inactivation obtained for 14 and 17 were much lower than piperine, and correlated with the intenstity of inhibition of MOC dealkylation in hepatoma cell cultures (Table 5). 


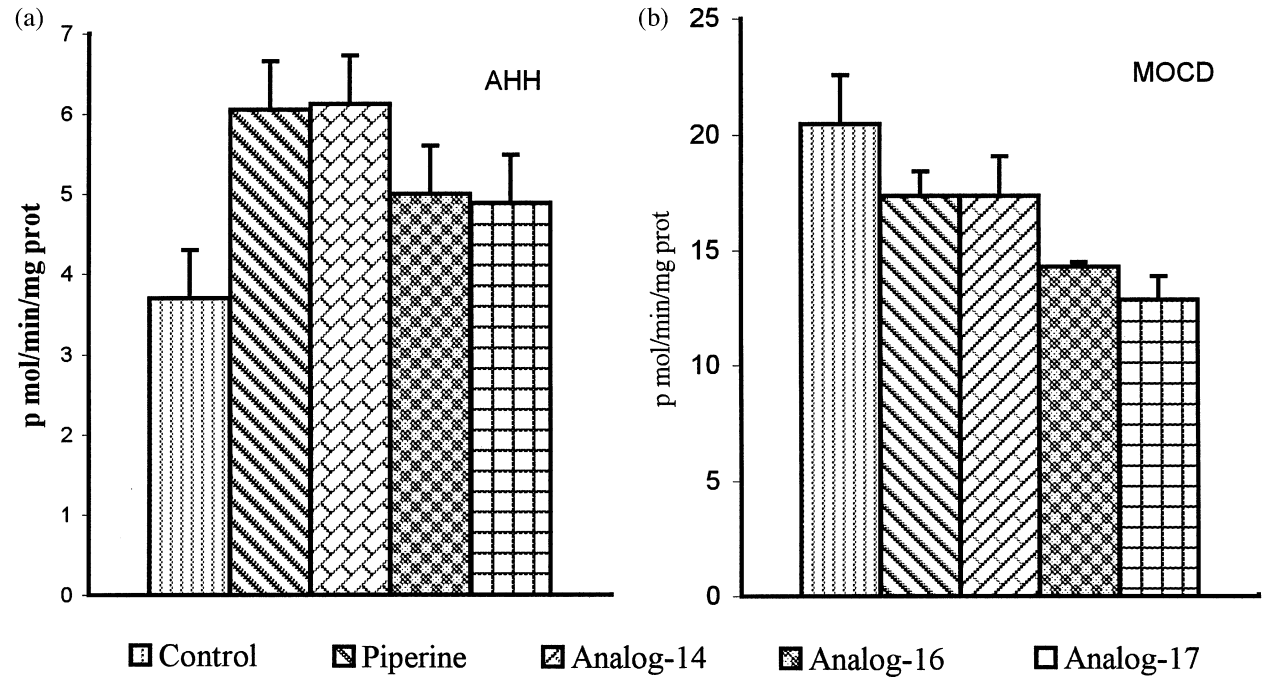

Figure 2. Influence of piperine and its synthetic analogues on monooxygenase activities in rat hepatoma cells. Rat Reuber hepatoma H4IIEC3/Gcells $\left(1 \times 10^{6}\right)$ were seeded in $90 \mathrm{~mm}$ tissue culture plates and allowed to grow for $48 \mathrm{~h}$. The medium was changed with fresh medium and cultures were treated with $60 \mu \mathrm{M}$ piperine or anologues in $15 \mu \mathrm{L} \mathrm{DMSO} /$ plate as vehicle. After $27 \mathrm{~h}$ of exposure, medium was removed, cultures washed with PBS $\times 2$. Cells were scrapped and collected in PBS and centrifuged. The cell pellet was stored in liquid nitrogen. Before assay of monooxygenases the pellet was suspended in $0.5 \mathrm{~mL}$ of $50 \mathrm{mM}$ Tris $-\mathrm{HCl}$, $\mathrm{pH}$ 7.4. Other conditions were the same as described in Materials and Methods. The data are mean \pm SD from four culture plates. $P<0.05$ (Student's ' $t$ ' test).

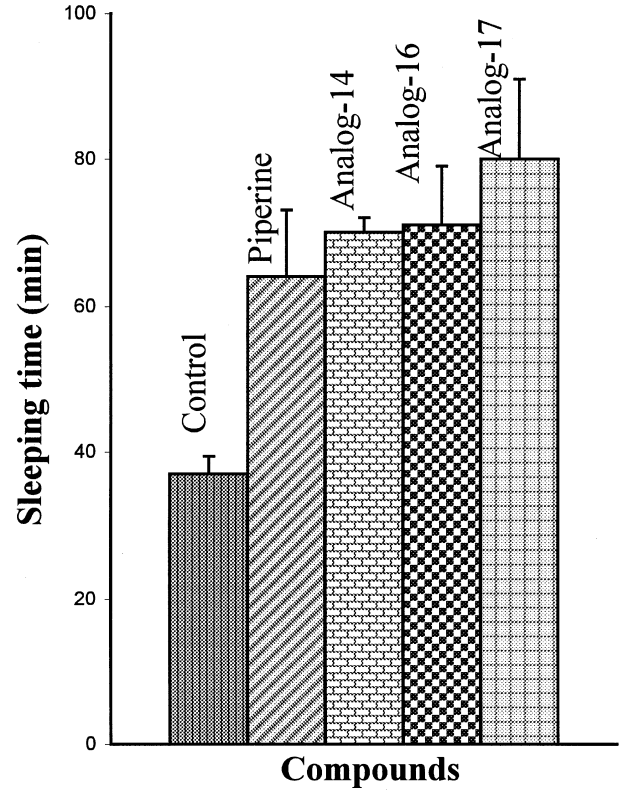

Figure 3. Influence of piperine analogues on the hexobarbital-induced sleeping time in mice. Compounds were administered $(5 \mathrm{mg} / \mathrm{kg}$ body wt, ip) $30 \mathrm{~min}$ before hexobarbital $(60 \mathrm{mg} / \mathrm{kg}$ body wt, ip). Data are mean $\pm \mathrm{SD}(n=4) . P$ values $<0.01$ (Student's ' $t$ ' test).

\section{Discussion}

The present studies have been undertaken to relate the role of various functional groups in piperine molecule to the inhibition of constitutive and inducible CYP activities of rat liver by employing the oxidation of marker CYP substrates of CYP1A and CYP2 gene families. The results suggested that (i) all the three components of piperine, viz. MDP ring, side chain and the piperidine moiety together, are essential for maximal inhibition of both the constitutive and inducible AHH and MOCD
Table 6. Comparative effect of piperine analogues on the kinetics of MOC demethylation by rat liver microsomes in vitro ${ }^{\mathrm{a}}$

\begin{tabular}{lcccccc}
\hline & \multicolumn{3}{c}{$V_{\max }(\mathrm{pmol} / \mathrm{min} / \mathrm{mg}$ protein $)$} & $K_{\mathrm{m}}(\mu \mathrm{M})$ & $K_{\mathrm{i}}(\mu \mathrm{M})$ \\
\cline { 2 - 5 } Compound & $0 \mu \mathrm{M}$ & $15 \mu \mathrm{M}$ & $30 \mu \mathrm{M}$ & $60 \mu \mathrm{M}$ & & \\
\hline Piperine & 278 & 242 & 194 & 125 & 151 & 50 \\
$\mathbf{1 4}$ & 283 & 193 & 133 & 96 & 150 & 35 \\
$\mathbf{1 7}$ & 284 & $\mathrm{ND}^{\mathrm{b}}$ & 143 & 100 & 152 & 42 \\
\hline
\end{tabular}

avalues derived from Lineweaver-Burk double reciprocal and Dixon plots of MOC dealkylation by microsomal MOCD from untreated rat liver in the presence and absence of indicated inhibitors.

${ }^{\mathrm{b}} \mathrm{ND}$, not determined.

activities and that (ii) the modification of any one moiety in the piperine molecule may not only alter the status of inhibition but also could elicit differential inhibition of the two types of monooxygenase activities examined.

Piperine was shown earlier to inhibit the oxidation of benzo(a)pyrene, 7-ethoxy-O-coumarin and ethylmorphine in untreated, $3 \mathrm{MC}$ - and PB-treated rat liver. ${ }^{2}$ In this study we examined the oxidation of two types of CYP substrates $\mathrm{B}(\mathrm{a}) \mathrm{P}$ and $\mathrm{MOC}$ by using microsomes from untreated, 3MC- and PB- pre-treated rat liver. Because we have earlier reported that piperine inhibits at least two CYP-dependent marker reactions, viz. arylhydrocarbon $\mathrm{B}(\mathrm{a}) \mathrm{P}$ hydroxylase $(\mathrm{AHH})$ and 7-methoxycoumarin $O$-demethylase (MOCD) in H4IIEC3 cells. ${ }^{39}$ The former reaction primarily is mediated by members of CYP family which are inducible by polycyclic aromatic hydrocarbons, i.e. CYP1A. ${ }^{20}$ The later is catalyzed by constitutive, phenobarbital or dexamethasone inducible CYP forms comprising members of CYP2 and CYP3 families. ${ }^{13,21}$ Further, MOCD activity was observed in preparations of genetically constructed V79 cells (SD1) containing only CYP2B1, the major PB-inducible CYP 
of rat liver and not in XEM1 cells containing only CYP1A $1 .{ }^{21}$

From the two CYP marker reactions studied against several analogues of piperine, some interesting features emerged about the structure-activity relationship on the inhibition of mono-oxygenase activities examined. For instance all the three structural components in piperine molecule occuring in nature are essential for overall inhibition. In the case of $\mathrm{AHH}$ various compounds with modified MDP ring in general were insensitive to both constitutive and inducible AHH with only the exception of 25. However, the inhibition becomes selective in favour of the constitutive AHH only when the conjugated side chain is saturated with or without any alteration in the basic moiety $(\mathbf{1 4}, \mathbf{1 5}, \mathbf{1 6}, \mathbf{1 7})$. This suggested that differences in the protein domain in active site architecture exist between the constitutive and inducible CYP1A1 enzymes. Saturation of the side chain of piperine induces flexibility in the molecule which may facilitate interaction of the inactivator with protein domain and may thereby enhance constraints for orientation of the CYP substrates to the active site. On the other hand, compounds $\mathbf{3 2}$ and $\mathbf{3 3}$ are short by one double bond which not only confers rigidity in the molecule but also renders them selective inhibitors of only inducible AHH activity. Saturation of the conjugated double bonds to tetrahydro-derivatives of MDP ring appear to result in higher flexibility of the side chain which perhaps acts as a handle to orient MDP group to the active site of the CYP450 anchored in a strong hydrophobic environment. Thus, altering the functional groups in piperine would determine its interaction with the hydrophobic environment of the active site and hence its potential to determine the specificity and extent of inhibition. In addition, the lipophillic nature of the synthetic analogues also influences strongly the inhibition of AHH and MOCD. This is evidenced from the facts that compounds $\mathbf{1 4}$ and $\mathbf{1 6}$ have displayed higher inhibition than their unsaturated counterpart 11. The latter although, it is a tetrahydro derivative, has displayed null inhibition due to quaternary ammonium salt which imparts higher water solubility to the compound. This also suggests the significance of 5-carbon ring or piperidine molecule in supplementing the hydrophobicity of piperine. Synthesis of such compounds thus appear useful in undestanding the environment of active site of different CYP enzymes.

Certain substituted methylenedioxy benzenes are also known as synergists for a number of classes of pesticides of different structure types ${ }^{40}$ which act by inhibition of drug biotransformation. MDP ring is generally considered to require hepatic metabolism for inhibition of microsomal oxidation through an active metabolite carbene. ${ }^{41,42}$ Part of the inhibitory action of MDP-related compounds is due to the metabolite intermediate (MI) complexation of CYP. Food flavouring agent isosafrol forms MI complex selectively with PB-inducible CYP2B1 and MC-inducible 1A2. ${ }^{13}$ This inhibition in general was not observed with various compounds we synthesised with change in substitutions in phenyl nucleus. The importance of the methylendioxy carbon in the induction of CYP450 has also been demonstrated earlier ${ }^{43}$ despite the fact that these compounds are found potent inhibitors of mixed function oxidases both in vitro and in vivo. ${ }^{44,45}$ The noncompetitive inhibition of mixed function oxidases by MDP compounds essentially appears due to the binding of MDP metabolite to reduced CYP. ${ }^{46} \mathrm{We}$ observed earlier that piperine is not a suicidal inhibitor of monooxygenases. It was found that despite its ability to activate moderately CYP1A1 gene transcription, the alkaloid regulate CYP1A1 gene expression posttranslationally where it inhibits its catalytic activity by binding with the enzyme without destroying the AHH. ${ }^{7}$ However, it is not known that which CYP form (s) is involved in the metabolism of piperine.

In contrast to the $\mathrm{B}(\mathrm{a}) \mathrm{P}$ oxidation by CYP1A family, MOC is a preferred substrate for liver constitutive and PB-inducible CYPs. ${ }^{21} \mathrm{~PB}$ induces several CYP members of CYP2 (A1, B1, B2, B4, C5, C6) and CYP3 (A2, A4) families. ${ }^{13}$ We do not know the relative preference of each isoform to MOC dealkylation. Under such circumstances it is not easy to design inhibitors of sufficient selectivity to target individual CYP isoforms because of several forms of CYP and wide range of overlapping substrates specificty. However, after introducing structural alterations in piperine a number of compounds synthesised exhibited preferential selectivity either towards constitutive or inducible CYPs $(\mathbf{2 5}, \mathbf{2 9}$, 30). These compounds relatively exhibited maximal selectivity and higher CYP inactivating potency than the parent molecule as evidenced by their effect on microsomal MOCD activities. However, unlike insensitivity to the MC-inducible $\mathrm{AHH}$ activity, the tetrahydroderivatives $(\mathbf{1 4}, \mathbf{1 5}, \mathbf{1 6}, \mathbf{1 7})$ were equipotent to both constitutive and inducible forms while analogues $\mathbf{1 4}$ and 17 exhibited higher sensitivity than piperine. It appears that the presence of the side chain with saturated double bonds linked through amide linkage appeared to impart specificity for inhibiting different forms of CYP450s. This in turn would again depend upon the amino acids located in the putative substrate recognition sites of CYP which regulate the accessibility of the substrates to generate MI which would sequester CYP to modulate drug biotransformation. In fact, it would require further studies to test these selected analogues for their specificity and selectivity with individual CYP members.

Besides studying the relationship of functional groups of piperine with the inhibition of CYP activities, we attempted to compare the potency of some analogues such as 14, 16 and 17 with piperine in different systems in vitro and in vivo. These compounds were insensitive to 3MC-inducible but expressed higher sensitivity to constitutive $\mathrm{AHH}$ and as well as to constitutive and inducible MOCD. This type of response was also evident from experiments on sleeping time in mice, and monooxygenase inhibition in the hepatoma cells pretreated with inducers. Poor inducibility of AHH by $\mathbf{1 6}$ and 17 compared to piperine in this regard was interesting when cells were exposed to these anologues for longer period while they inhibited the enzymes strongly 
during initial period. Like piperine, ${ }^{2}$ the noncompetitive nature of inhibition was not altered by tetrahydroderivatives, the $K_{\mathrm{i}}$ values however, were further lowered compared to piperine although $K_{\mathrm{m}}$ value was similar in each case. Similarly, other selective compounds such as 20, 23, 25 and 35 could be tested for selectivity and specificity against certain pesticides as synergists or for enhancing the bioavailability of some therapeutically important drugs.

\section{Conclusion}

In conclusion, the structure of piperine is ideally suited to affect the microsomal oxidation of large number of compounds. Piperine has a number of inherent advantages in that it is a simple molecule, can be used with intact cells in culture and in vivo, easily available commercially, and a highly indispensable ingredient of spices in platability of food used for ages. Presence of piperidine function at the terminal end of conjugated double bond in the side chain and MDP ring offered differential sensitivity in inhibiting the CYP450 activities examined in the present study. By introducing modifications at different positions desired inhibitors of drug metabolism with strong implications in agriculture and pharmaco-toxicology could be developed We have earlier reported that presence of unsaturated double bonds in the side chain of piperine molecule are responsible for inhibition of UDP-glucose dehydrogenases ${ }^{6}$ and certain dehydrogenase complex associated with electron transport chain ${ }^{47}$ in vitro. This drawback is obviously removed by saturating the double bond and simultaneously increasing the potential drug inhibitory property of the molecule. Modifications of piperine molecule may thus prove useful in the development of selective CYP inhibitors.

\section{Experimental}

\section{Chemistry}

General methods. Reagents for chemical synthesis were of AR grade and obtained commercially. All reactions were monitored by TLC carried out on $0.25 \mathrm{~mm} \mathrm{E}$. Merck silica gel plates using UV light. Silica gel of mesh size $60-120$ was used for column chromatography. ${ }^{1} \mathrm{H}$ NMR spectra were determined at either $60 \mathrm{MHz}$ or $90 \mathrm{MHz}$ using Varian F-60 or Jeol Fx-90 spectrometers, respectively. Mass spectra were determined on Jeol MSD-300 mass spectrometer while IR spectra were recorded on Perkin-Elmer FT-IR spectrometer.

Preparation of substituted aryl pentadienoic acid amides and other derivatives. The structure of piperine (Fig. 1) may be divided into three main components, i.e. methylenedioxyphenyl part, a conjugated side chain and piperidine moiety. For the preparation of its synthetic analogues modifications were envisaged in all the three components. The key intermediate, the substituted phenyl-2E,4E-pentadienoic acid was constructed starting from corresponding benzaldehyde in a five-step reaction sequence via cinnamaldehyde intermediate as depicted in Scheme 1. The amides were readily obtained from the carboxylic acids through acyl chloride formation<smiles>[R]c1ccc(C=CC=O)cc1</smiles>

1

2

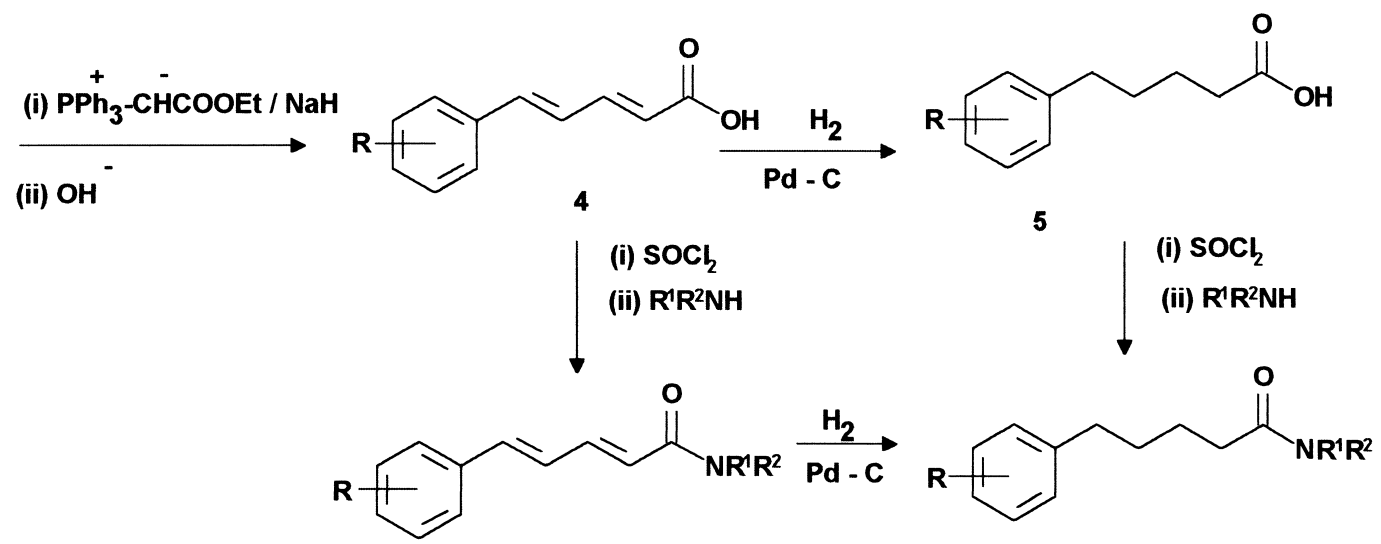


and condensation with appropriate amines. For the synthesis of pyrano analogues, the required benzopyran moiety was prepared from the corresponding phenols by condensing with isoprene in presence of an acid (Scheme 3) which is followed by the same reaction sequence as described in Scheme 1. The synthesis of substituted phenyl-2E-propenoic acid is shown in Schemes 2 and 3. The tetrahydro-analogues were obtained by catalytic reduction of the phenylpentadienoic acid or the phenylpentadienoamides in presence of palladium-charcoal $(10 \%)$. The structure analysis was carried out mainly through elemental analysis, IR, PMR and MS studies. Various compounds synthesized through Schemes 1-3 are given in Table 1.

Preparation of $\alpha$-methyl-4-methoxy benzyl alcohol (2a). To an ethereal solution of $\mathrm{Mg}$ metal $(2.6 \mathrm{~g}, 110 \mathrm{mmol})$ and methyl iodide $(9.8 \mathrm{~mL}, 130 \mathrm{mmol})$ added an ethereal solution of $p$-anisaldehyde (1a) $(15 \mathrm{~mL}, 110 \mathrm{mmol})$ and the contents stirred for $2 \mathrm{~h}$ at $0-5^{\circ} \mathrm{C}$. The reaction mixture worked up by adding saturated aqueous solution of ammonium chloride $(10 \mathrm{~mL})$, followed by dilution with water $(100 \mathrm{~mL})$, separation of organic layer followed by extraction of aqueous layer with solvent ether $(2 \times 100 \mathrm{~mL})$. The combined organic layer washed with water $(2 \times 20 \mathrm{~mL})$, dried over anhydrous sodium sulfate and concentrated in vacuo to give a gummy mass (2a) $(16.0 \mathrm{~g}, 95 \%)$ analysed for $\mathrm{C}_{9} \mathrm{H}_{12} \mathrm{O}_{2}$, MS $(\%) \mathrm{M}^{+}$at $m / z 152$ (36), 137 (57), 134 (100), 109 (62), 106 (14), 103 (10), $94(50), 91(62)$ and $78(19) . v \mathrm{~cm}^{-1}(\mathrm{KBr}) 3352$, $2968,1612,1588,1510,1450,1422,1300,1242,1174$, $1068,1030,1016,888$ and $810 .{ }^{1} \mathrm{H}$ NMR $\left(\mathrm{CDCl}_{3}\right) \delta 1.45$ $\left(3 \mathrm{H}, \mathrm{d}, J=6.5 \mathrm{~Hz}, \mathrm{CH}_{3}-\mathrm{C}-\mathrm{OH}\right), 3.80\left(3 \mathrm{H}, \mathrm{s}, \mathrm{OCH}_{3}\right)$, $4.80\left(1 \mathrm{H}, \mathrm{q}, J=6.5 \mathrm{~Hz} \mathrm{CH}_{3}-\mathrm{CHOH}\right), 6.90(2 \mathrm{H}, \mathrm{d}$, $J=8.5 \mathrm{~Hz} 2 \times \mathrm{Ar}-\mathrm{H})$ and $7.28(2 \mathrm{H}, \mathrm{d}, J=8.5 \mathrm{~Hz}$, $2 \times \mathrm{Ar}-\mathrm{H})$.

Preparation of 3-(4-methoxy phenyl)-2E-propenal (3a). To a chilled solution of (2a) $(12.2 \mathrm{~g}, 80 \mathrm{mmol})$ in DMF $(15 \mathrm{~mL})$ added phosphoryl chloride $(7 \mathrm{~mL})$ slowly at $0-5^{\circ} \mathrm{C}$ for $1 \mathrm{~h} .{ }^{23}$ The contents were stirred further for $2 \mathrm{~h}$ and then allowed to attain room temperature followed by heating on a water bath for $3 \mathrm{~h}$. The reaction mixture cooled and a saturated solution of sodium acetate $(15 \mathrm{~mL})$ added, followed by dilution with water $(150 \mathrm{~mL})$. The contents of the reaction mixture were extracted with ethylacetate $(5 \times 100 \mathrm{~mL})$, the organic layer washed with water $(3 \times 30 \mathrm{~mL})$ and dried over anhydrous sodium sulfate to give crude product which on $\mathrm{CC}$ over $\mathrm{SiO}_{2}$ and elution with pet.ether:ethyl acetate (9:1) gave yellow crystalline compound (3a) (8.4 g, $65 \%$ ), mp $58^{\circ} \mathrm{C}$ (lit. mp. $56-57^{\circ} \mathrm{C}$ ), ${ }^{24}$ analysed for
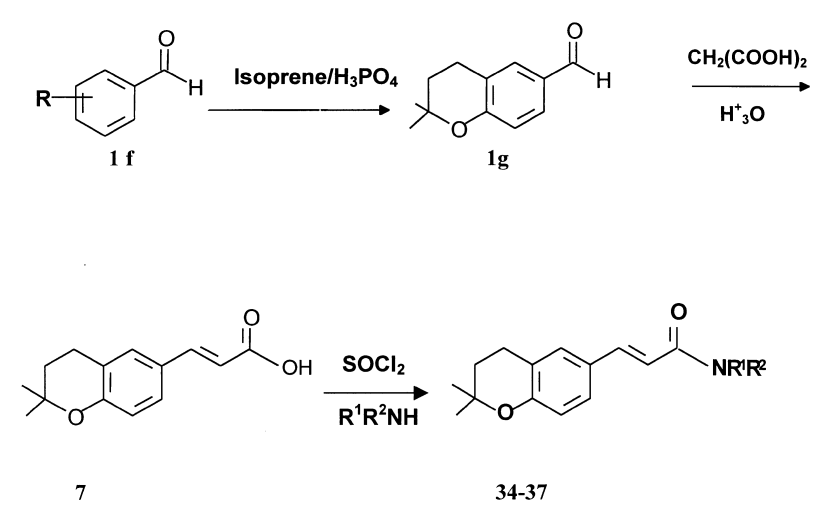

Scheme 3. $\mathrm{R}^{1} \mathrm{R}^{2} \mathrm{NH}$ : piperidine, pyrrolidine, diethylamine, $n$-butylamine, $n$-pentylamine, isopropylamine, isobutylamin, $n$-methylpiperazine and $n$-hexylamine. S. No. R (a) 4-methoxy; (b) 3,4-dimethoxy; (c) 3,4-ethylendedioxy; (d) 4-benzyloxy-3-methoxy; (e) 3,4,5,-trimethoxy; (f) 4-hydroxy; (g) [2H]-2,2-dimethyl-3,4-dihydro pyranyl; (h) 3,4-methylendioxy.

$\mathrm{C}_{10} \mathrm{H}_{10} \mathrm{O}_{2}$, MS (\%) $\mathrm{M}^{+}$at $m / z$ 162. $v \mathrm{~cm}^{-1}(\mathrm{KBr}) 1694$, $1650,1600,1582,1500,1462,1334,1246,1124,996$ and 818. ${ }^{1} \mathrm{H} \mathrm{NMR}\left(\mathrm{CDCl}_{3}\right)$ $\delta: 3.90\left(3 \mathrm{H}, \mathrm{s}, \mathrm{OCH}_{3}\right), 6.57(1 \mathrm{H}$, $\mathrm{d} \mathrm{d}, J=16.0 \mathrm{~Hz}$ and $7.0 \mathrm{~Hz},-\mathrm{CH}=\mathrm{CH}-\mathrm{CO}), 6.78$ $(2 \mathrm{H}, \mathrm{d}, J=8.5 \mathrm{~Hz}, 2 \times \mathrm{Ar}-\mathrm{H}), 7.43(1 \mathrm{H}, \overline{\mathrm{d}}, J=16.0 \mathrm{~Hz}$, $-\mathrm{CH}=\mathrm{CH}-\mathrm{CO}), 7.46(2 \mathrm{H}, \mathrm{d}, J=8.5 \mathrm{~Hz}, 2 \times \mathrm{Ar}-\mathrm{H})$ and $9.73(1 \mathrm{H}, \mathrm{d}, J=7.0 \mathrm{~Hz},=\mathrm{CH}-\mathrm{CHO})$.

Preparation of 5-(4-methoxy phenyl)-2E,4E-pentadienoic acid (4a). To a stirring mixture of (3a) $(6.5 \mathrm{~g}, 40 \mathrm{mmol})$ and the ylide, prepared from ethyl bromoacetate $(4.8 \mathrm{~mL}, 44 \mathrm{mmol})$ and triphenyl phosphine $(11.7 \mathrm{~g}$, $44 \mathrm{mmol})$, in dry dimethoxy ethane $(100 \mathrm{~mL})$ was added sodium hydride $(2.0 \mathrm{~g})$ in small proportions. The progress of the reaction monitored by TLC; after the completion of the reaction, the contents poured carefully in ethyl acetate to quench the excess of sodium hydride, followed by addition of water, the organic layer separated and the aqueous layer extracted with ethyl acetate $(3 \times 125 \mathrm{~mL})$. The combined organic layer washed with water $(3 \times 40 \mathrm{~mL})$, dried over anhydrous sodium sulfate and concentrated in vacuo. The crude solid product taken up in $10 \%$ methanolic $\mathrm{KOH}$ solution $(140 \mathrm{~mL})$ and the contents refluxed on water bath for $6 \mathrm{~h}$. On cooling, the contents were diluted with water $(300 \mathrm{~mL})$ and extracted with ethyl acetate $(3 \times 25 \mathrm{~mL})$. The aqueous phase washed with petroleum ether $(30 \mathrm{~mL})$ and then acidified with $2 \mathrm{~N} \mathrm{HCl}$ solution. The resulting precipitate filtered, washed with ice cold water and dried to give acid (4a) $(6.7 \mathrm{~g}, 82 \%)$ crystallised from ethyl acetate:petroleum ether $(9: 1)$ as colourless compound, mp $183^{\circ} \mathrm{C}$ (lit. mp $182-183^{\circ} \mathrm{C}$ ), ${ }^{23,25,26}$ analysed<smiles>[R]c1ccc(C=O)cc1</smiles>

1h

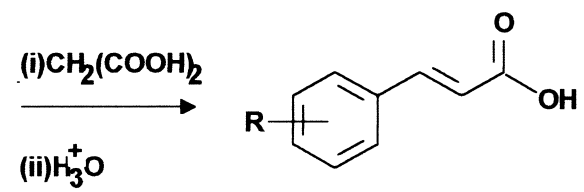

6

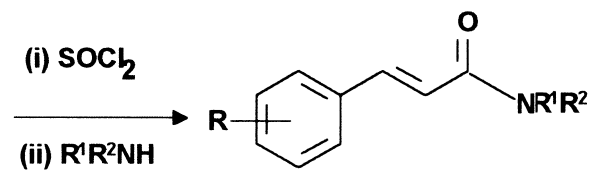

32, 33 
for $\mathrm{C}_{12} \mathrm{H}_{12} \mathrm{O}_{3}$, MS (\%) $\mathrm{M}^{+}$at $m / z$ 204. $v \mathrm{~cm}^{-1}(\mathrm{KBr})$ 2960, 1688, 1668, 1612, 1550, 1440, 1320, 1040, 960 and 810. ${ }^{1} \mathrm{H}$ NMR (acetone- $\left.d_{6}\right) \delta 3.90\left(3 \mathrm{H}, \mathrm{s}, \mathrm{OCH}_{3}\right), 6.10$ $(1 \mathrm{H}, \mathrm{d}, J=15.0 \mathrm{~Hz},-\mathrm{CH}=\mathrm{CH}-\mathrm{CO}), 6.60-7.13(3 \mathrm{H}, \mathrm{m}$, olefinic and $\mathrm{Ar}-\mathrm{H})$ and $7.4 \overline{0-8.20}(4 \mathrm{H}, \mathrm{m}$, olefinic and $\mathrm{Ar}-\mathrm{H})$.

Preparation of 5-(4-methoxy phenyl)-2E,4E-pentadienoic acid piperidine amide (8). To the acid (4a) (2.0 g, $10 \mathrm{mmol})$ in dry methylene chloride $(50 \mathrm{~mL})$ added freshly distilled thionyl chloride $(0.8 \mathrm{~mL})$ and refluxed for $1 \mathrm{~h}$, excess of thionyl chloride removed in vacuo and thereafter condensed with methylenechloride solution of piperidine $(1 \mathrm{~mL})$ and stirred for $30 \mathrm{~min}$. The organic layer washed with water $(2 \times 25 \mathrm{~mL})$, dried over anhydrous sodium sulfate and concentrated to give crude product which on $\mathrm{CC}$ over $\mathrm{SiO}_{2}$ and elution with pet. ether:ethyl acetate (4:1), yielded colourless crystalline compound $8(2.56 \mathrm{~g}, 94 \%), \mathrm{mp} 135^{\circ} \mathrm{C}$ (lit. mp $\left.97^{\circ} \mathrm{C}\right),{ }^{25}$ (analysed for $\mathrm{C}_{17} \mathrm{H}_{21} \mathrm{NO}_{2}$; found $\mathrm{C} 75.2481, \mathrm{H} 7.8004$, N 5.1637; calcd C 75.2463, H 7.7999, N 5.1618) MS (\%) $\mathrm{M}^{+}$at $m / z 271$ (48), 187 (100), 159 (39), 129 (40), 115 (60) and $84(10) . v \mathrm{~cm}^{-1}(\mathrm{KBr}) 2930,1640,1600,1560$, 1450, 1320, 1250, 1110, 1050 and 970. ${ }^{1} \mathrm{H}$ NMR $\left(\mathrm{CDCl}_{3}\right) \delta: 1.50\left(6 \mathrm{H}\right.$, bs, $\left.-\mathrm{N}-\mathrm{CH}_{2}-\left(\mathrm{CH}_{2}\right)_{3}\right), 3.36(4 \mathrm{H}$, $\mathrm{m}, \mathrm{N}-\left(\mathrm{CH}_{2}\right)_{2}, 3.82\left(3 \mathrm{H}, \mathrm{s}, \mathrm{OCH}_{3}\right), 6.36(1 \mathrm{H}, \mathrm{d}$, $J=15.0 \mathrm{~Hz}, \mathrm{CH}=\mathrm{CH}-\mathrm{CO}) 6.80-7.00(6 \mathrm{H}, \mathrm{m}$, olefinic and $\mathrm{Ar}-\mathrm{H})$ and $7 . \overline{25}(1 \mathrm{H}$, dd. $J=15.0 \mathrm{~Hz}$ and $7.0 \mathrm{~Hz}$, $-\mathrm{CH}-\mathrm{CH}=\mathrm{CH}-\mathrm{CO})$.

Preparation of 5-(4-methoxyphenyl)-2E,4E-pentadienoic acid pyrrolidine amide (9). Compound (9) was prepared from acid (4a) $(1.0 \mathrm{~g}, 5 \mathrm{mmol})$ using thionyl chloride $(0.4 \mathrm{~mL})$ and pyrrolidine $(0.5 \mathrm{~mL}, 6 \mathrm{mmol})$ by the same method as described for $\mathbf{8}$ to give a crude product which on $\mathrm{CC}$ over $\mathrm{SiO}_{2}$ and elution with pet.ether: ethyl acetate (4:1) furnished white crystalline compound (1.18 g, 91.8\%), mp. $137^{\circ} \mathrm{C}$ (analysed for $\mathrm{C}_{16} \mathrm{H}_{19} \mathrm{NO}_{2}$; found C 74.6824, H 7.4421, N 5.4451; calcd C 74.6804, $\mathrm{H} 7.4418$, N 5.4431). MS (\%) $\mathrm{M}^{+}$at $m / z 257$ (35) 187 (100) 159 (12) 129 (16) 116 (32) and 70 (38). vcm $\mathrm{vc}^{-1}$ (KBr) 2955, 1630, 1600, 1520, 1485, 1436, 1310, 1250, $1184,1136,1022,838$ and $732 .{ }^{1} \mathrm{H} \mathrm{NMR}\left(\mathrm{CDCl}_{3}\right) \delta$ : $1.93\left(4 \mathrm{H}, \mathrm{m},\left(\mathrm{CH}_{2}\right)_{2}\right), 3.56\left(4 \mathrm{H}, \mathrm{m},-\mathrm{N}\left(\mathrm{CH}_{2}\right)_{2}\right) 3.85(3 \mathrm{H}$, $\left.\mathrm{s}, \mathrm{OCH}_{3}\right), 6.23(1 \mathrm{H}, \mathrm{d}, \mathrm{J}=15 \mathrm{~Hz}, \mathrm{CO}-\mathrm{CH}=\mathrm{CH}), 6.66-$ 7.00 and $7.20-7.75(7 \mathrm{H}, \mathrm{m}$, olefinic and $\overline{\mathrm{Ar}}-\mathrm{H})$.

Preparation of 5-(4-methoxy phenyl)-2E,4E-pentadienoic acid $N$-methyl piperazine amide (10). Compound (10) was prepared from acid (4a) $(2.0 \mathrm{~g}, 10 \mathrm{mmol})$ using thionyl chloride $(0.8 \mathrm{~mL})$ and $N$-methyl piperazine $(1.0 \mathrm{~mL}, 11 \mathrm{mmol})$ by the method as described for 8 to give a crude product which on $\mathrm{CC}$ over $\mathrm{SiO}_{2}$ and elution with pet.ether:ethyl acetete furnished white crystalline compound, $(2.45 \mathrm{~g}, 86 \%)$, mp $201-202{ }^{\circ} \mathrm{C}$ (analysed for $\mathrm{C}_{17} \mathrm{H}_{22} \mathrm{~N}_{2} \mathrm{O}_{2}$; found $\mathrm{C}$ 71.3139, $\mathrm{H}$ 7.7420, $\mathrm{N}$ 9.7852; calcd C 71.3011, H 7.7429, N 9.7823). MS (\%) $\mathrm{M}^{+}$at $m / z 286$ (46), 187 (100), 159 (31), 144 (28), 116 (14) and 99 (15). vcm ${ }^{-1}(\mathrm{KBr}) 3250,2930,1640,600,1560,1420$, 1310, 1250, 1020 and 970. ${ }^{1} \mathrm{H} \mathrm{NMR}\left(\mathrm{CDCl}_{3}\right) \delta 2.95$ $\left(3 \mathrm{H}, \mathrm{s},-\mathrm{N}-\mathrm{CH}_{3}\right), 3.20\left(4 \mathrm{H}, \mathrm{m},-\mathrm{N}-\left(\mathrm{CH}_{2}\right)_{2}\right), 3.50(4 \mathrm{H}, \mathrm{m}$, $\left.-\mathrm{N}-\left(\mathrm{CH}_{2}\right)_{2}\right), 3.92\left(3 \mathrm{H}, \mathrm{s}, \mathrm{OCH}_{3}\right), 6.30(1 \mathrm{H}, \mathrm{d}$, $J=15 . \overline{\mathrm{Hz}} \mathrm{CH}=\mathrm{CH}-\mathrm{CO}), 6.80-7.00(6 \mathrm{H}, \mathrm{m}$, olefinic and $\mathrm{Ar}-\mathrm{H})$ and $7.30(1 \mathrm{H}, \mathrm{dd}, J=15.0 \mathrm{~Hz}$ and $7.0 \mathrm{~Hz}$, $\mathrm{CH}-\mathrm{CH}=\mathrm{CH}-\mathrm{CO})$.

Preparation of 5-(4-methoxy phenyl) pentanoic acid $N$ methyl piperazine amide (11). To the compound (10) $(0.57 \mathrm{~g}, 2 \mathrm{mmol})$ in ethylacetate $(30 \mathrm{~mL})$ added $\mathrm{Pd} / \mathrm{C}$ $(5 \%, 30 \mathrm{mg})$ and hydrogenated the contents at $30 \mathrm{psi}$. Work up of the reaction mixture afforded $11(0.54 \mathrm{~g}$, $93 \%$ ), mp $183{ }^{\circ} \mathrm{C}$ (analysed for $\mathrm{C}_{17} \mathrm{H}_{26} \mathrm{~N}_{2} \mathrm{O}_{2}$; found $\mathrm{C}$ 70.3172, H 9.0280, N 9.6507; calcd C 70.3112, H 9.0237, $\mathrm{N}$ 9.6465). MS (\%) $\mathrm{M}^{+}$at $m / z 290$ (32), 191 (100) 163 (46) 148 (10) 120 (48) and 99(15). vcm $\mathrm{cm}^{-1}$ (KBr) 2972, 1640, 1560, 1450, 1350, 1310, 1250, 1128, 1010, 930 and 827. ${ }^{1} \mathrm{H} \mathrm{NMR}\left(\mathrm{CDCl}_{3}\right) \delta 1.60\left(4 \mathrm{H}, \mathrm{bs},\left(\mathrm{CH}_{2}\right)_{2}\right), 2.50$ (4H, m, Ar- $\left.\mathrm{CH}_{2}-\mathrm{CH} 2-\mathrm{CO}\right), 3.10\left(3 \mathrm{H}, \mathrm{bs},-\mathrm{N}-\mathrm{CH}_{3}\right)$, $3.40-3.70\left(8 \mathrm{H}, \overline{\mathrm{m}}, 2 \times-\mathrm{N}\left(\mathrm{CH}_{2}\right)_{2} 3.86\left(3 \mathrm{H}, \mathrm{s}, \mathrm{OCH}_{3}\right)\right.$ and 6.60-7.00 (4H, m, Ar-H).

Preparation of 5-(3,4-methylenedioxy phenyl)-2E,4Epentadienoic acid (piperic acid) 4h. Piperine $(28.0 \mathrm{~g}$, $98 \mathrm{mmol}), \mathrm{mp} 132^{\circ} \mathrm{C}$, dissolved in ethylene glycol $(200 \mathrm{~mL})$ and refluxed at $180^{\circ} \mathrm{C}$ after adding potassium hydroxide $(25 \mathrm{~g})$ and after the completion of the reaction the contents diluted with sufficient amount of water and acidified with $2 \mathrm{~N} \mathrm{HCl}$. The resulting precipitate filtered and dried to give crude product which on crystallisation from ethanol gave $\mathbf{4 h}$ as pale yellow solid $(13.8 \mathrm{~g}, 65 \%) \mathrm{mp} 217^{\circ} \mathrm{C}$ (lit. $\left.\mathrm{mp} 217^{\circ} \mathrm{C}\right) .{ }^{27}$

Preparation of 5-(3,4-methylenedioxyphenyl)-2E,4E-pentadienoic acid pyrrolidine amide (12). Compound (12) was prepared from $4 \mathrm{~h}(2.2 \mathrm{~g}, 10 \mathrm{mmol})$ using thionylchloride $(0.9 \mathrm{~mL})$ and pyrrolidine $(0.95 \mathrm{~mL}, 11 \mathrm{mmol})$ by the same method as described for $\mathbf{8}$ to give a crude product which on crystallisation with pet.ether:ethylacetate (4:1) furnished a pale yellow crystalline compound $(2.46 \mathrm{~g}$, $90 \%$ ) mp $147^{\circ} \mathrm{C}$ (lit. mp. $144-146^{\circ} \mathrm{C}$ ) ${ }^{28}$ (analysed for $\mathrm{C}_{16} \mathrm{H}_{17} \mathrm{NO}_{3}$; found $\mathrm{C} 70.8444, \mathrm{H} \mathrm{6.3169,} \mathrm{N} \mathrm{5.1666;} \mathrm{calcd}$ C 70.8315, H 6.3152, N 5.1626); MS (\%) $\mathrm{M}^{+}$at $m / z 271$ (11) 201 (66) 173 (100) 143 (10) and $70(9) \cdot \mathrm{vcm}^{-1}(\mathrm{KBr})$ $1642,1616,1598,1505,1490,1450,1418,1364,1252$, 1194, 1148, 1142, 1038, 994, 932 and 844. ${ }^{1} \mathrm{H}$ NMR $\left(\mathrm{CDCl}_{3}\right) \delta 1.90\left(4 \mathrm{H}, \mathrm{m},\left(\mathrm{CH}_{2}\right)_{2}\right), 3.52\left(4 \mathrm{H}, \mathrm{m},-\mathrm{N}\left(\mathrm{CH}_{2}\right)_{2}\right)$, $5.93\left(2 \mathrm{H}, \mathrm{s}, \mathrm{O}-\mathrm{CH}_{2}-\mathrm{O}\right), 6.20(1 \mathrm{H}, \mathrm{d}, J=15 \mathrm{~Hz}$, $\mathrm{CO}-\mathrm{CH}=\mathrm{CH}), 6.62-7.50(6 \mathrm{H}, \mathrm{m}$, olefinic and $\mathrm{Ar}-\mathrm{H})$.

Preparation of 5-(3,4-methylenedioxy phenyl)-2E,4Epentadienoic acid $\boldsymbol{n}$-butyl amide (13). It was prepared from (4h) $(4.4 \mathrm{~g}, 20 \mathrm{mmol})$ using thionyl chloride and $n$ butyl amine $(2 \mathrm{~mL}, 20 \mathrm{mmol})$ employing the process as described for the preparation of $\mathbf{8}$, to give the amide (13) (4.6 g, 84\%), mp $144^{\circ} \mathrm{C}$ (lit. mp $\left.151-152^{\circ} \mathrm{C}\right)^{28}$ (analysed for $\mathrm{C}_{16} \mathrm{H}_{19} \mathrm{NO}_{3}$; found $\mathrm{C} 70.3120, \mathrm{H} 7.0071, \mathrm{~N} 5.1296$; calcd C 70.3019, H 7.0062, N 5.1245); MS (\%) $\mathrm{M}^{+}$at $m / z$ 273 (100), 216 (14), 201 (17), 173 (87), 152 (11), 143 (30), 135 (12), 115 (71) and $96(7) . \mathrm{vcm}^{-1}(\mathrm{KBr}) 3328,2936$, $1640,1550,1506,1490,1466,1442,1398,1364,1316$, 1248, 1208, 1192, 1100, 1042, 942 and 812. ${ }^{1} \mathrm{H}$ NMR $\left(\mathrm{CDCl}_{3}\right) \delta 0.97\left(3 \mathrm{H}, \mathrm{d}, J=6.5 \mathrm{~Hz} \mathrm{CH}_{2}-\mathrm{CH} 3\right), 1.48(4 \mathrm{H}, \mathrm{m}$, $\left.-\mathrm{C}-\left(\mathrm{CH}_{2}\right)_{2}\right), 3.36\left(2 \mathrm{H}, \mathrm{m},-\mathrm{NH}-\mathrm{CH}_{2}-\overline{\mathrm{CH}}_{2}\right), 5.92(1 \mathrm{H}, \mathrm{d}$, $\left.J=15.0 \mathrm{~Hz}-\mathrm{CH}=\mathrm{CH}-\mathrm{CO}), 5.96 \overline{(2 \mathrm{H}}, \mathrm{s},-\mathrm{O}-\mathrm{CH}_{2}-\mathrm{O}-\right)$, 6.64-7.00 (5H, m, olefinic and Ar-H) and 7.24-7.52 $(1 \mathrm{H}$, $\mathrm{m}, \mathrm{CH}=\mathrm{CH}-\mathrm{CO})$. 
Preparation of 5-(3,4-methylenedioxy phenyl) pentanoic acid (tetrahydro piperic acid) 5h. Piperic acid (4h) $(6.70 \mathrm{~g}, 31 \mathrm{mmol})$ was dissolved in methanol $(100 \mathrm{~mL})$ and to it was added $\mathrm{Pd} / \mathrm{C}(5 \%, 200 \mathrm{mg})$ and subjected to hydrogenation at 40 psi to yield tetrahydro piperic acid (5h) $\left(6.85 \mathrm{~g} \text { ), mp } 95^{\circ} \mathrm{C} \text { (lit. mp } 100-101{ }^{\circ} \mathrm{C}\right)^{29}$ analysed for $\mathrm{C}_{12} \mathrm{H}_{14} \mathrm{O}_{4}$.

Preparation of 5-(3,4-methylenedioxy phenyl) pentanoic acid piperidine amide (14). Compound $5 \mathrm{~h}(2.0 \mathrm{~g}, 9 \mathrm{mmol})$ was condensed with piperidine $(0.9 \mathrm{~mL})$ as described for 8 to yield a gummy mass $(2.4 \mathrm{~g}, 92 \%)$ (analysed for $\mathrm{C}_{17} \mathrm{H}_{23} \mathrm{NO}_{3}$; found $\mathrm{C} 70.5700, \mathrm{H}$ 8.0118, N 4.8434; calcd C 70.5619, H 8.0110, N 4.8404). MS (\%) $\mathrm{M}^{+}$at $m / z 289$ (50), 205 (100), 177 (47), 147 (57), 119 (32) and 84 (16). $v^{-1} \mathrm{~cm}^{-1}(\mathrm{KBr}) 2935,1640,1565,1440,1250,1020$ and 870. ${ }^{1} \mathrm{H} \mathrm{NMR}\left(\mathrm{CDCl}_{3}\right) \delta: 1.56\left(10 \mathrm{H}, \mathrm{m},-\mathrm{NCH}_{2}\left(\mathrm{CH}_{2}\right)_{3}\right.$ and $\left.-\mathrm{C}-\left(\mathrm{CH}_{2}\right)_{2}\right), 2.30\left(2 \mathrm{H}, \mathrm{t}, J=7.0 \mathrm{~Hz}, \mathrm{COCH}_{2}\right), 2.54(2 \mathrm{H}, \mathrm{t}$, $\left.J=7.0 \mathrm{~Hz}, \mathrm{Ar}-\mathrm{CH}_{2}\right), 3.46\left(4 \mathrm{H}, \mathrm{m},-\mathrm{N}-\left(\mathrm{CH}_{2}\right)_{2}\right), 5.82(2 \mathrm{H}$, $\left.\mathrm{s},-\mathrm{O}-\mathrm{CH}_{2}-\mathrm{O}-\right)$ and $6.62(3 \mathrm{H}, \mathrm{m}, \mathrm{Ar}-\mathrm{H})$.

Preparation of 5-(3,4-methylenedioxy phenyl) pentanoic acid pyrrolidine amide (15). To $5 \mathbf{h}(2.0 \mathrm{~g}, 9 \mathrm{mmol})$ dissolved in dry methylene chloride $(40 \mathrm{~mL})$ was added thionyl chloride $(0.8 \mathrm{~mL})$ and the resulting acid chloride condensed with pyrrolidine $(0.9 \mathrm{~mL})$ and worked up as described for compound $\mathbf{8}$ to furnish a gummy mass (15) $\left(2.40 \mathrm{~g}, 94 \%\right.$ ) (analysed for $\mathrm{C}_{16} \mathrm{H}_{21} \mathrm{NO}_{3}$; found $\mathrm{C}$ 69.7801, H 7.6874, N 5.0893; calcd C 69.7943, H 7.6870, N 5.0870). MS (\%) M + at $m / z 275$ (66), 148 (27), 126 (98), $113(100), 105(16), 98(57)$ and $70(75) \cdot \mathrm{vcm}^{-1}$ (KBr) 2960, 1640, 1550, 1455, 1350, 1305, 1268, 1120, 930 and 840. ${ }^{1} \mathrm{H}$ NMR $\left(\mathrm{CDCl}_{3}\right) \delta 1.38-1.94(8 \mathrm{H}, \mathrm{m}$, $\left.-\left(\mathrm{CH}_{2}\right)_{4}\right) 2.23\left(2 \mathrm{H}, \mathrm{t}, J=7.0 \mathrm{~Hz},-\mathrm{COCH}_{2}\right), 2.58(2 \mathrm{H}, \mathrm{t}$, $\left.J=7.0 \mathrm{~Hz}, \mathrm{Ar}-\mathrm{CH}_{2}\right), 3.33\left(4 \mathrm{H}, \mathrm{m},-\overline{\mathrm{N}}\left(\mathrm{CH}_{2}\right)_{2}\right), 5.90(2 \mathrm{H}$, s, $\left.-\mathrm{O}-\mathrm{CH}_{2}-\mathrm{O}-\right)$ and $6.65(3 \mathrm{H}, \mathrm{bs}, 3 \times \mathrm{Ar}-\mathrm{H})$.

Preparation of 5-(3,4-methylenedioxy phenyl)-pentanoic acid $n$-butyl amide (16). (5h) $(2.0 \mathrm{~g}, 9 \mathrm{mmol})$ was condensed with $n$-butyl amine $(1 \mathrm{~mL})$ by the method as described for $\mathbf{8}$ to yield $\mathbf{1 6}$ as a gummy mass $(2.0 \mathrm{~g}$, $98 \%$ ) (analysed for $\mathrm{C}_{16} \mathrm{H}_{23} \mathrm{NO}_{3}$; found $\mathrm{C} 69.2940, \mathrm{H}$ 8.3588 N 5.0522; calc. C 69.2871, H 8.3579, N 5.0500). MS $(\%) \mathrm{M}^{+}$at $m / z 277$ (49), 205 (100), 177 (33), 144 (36) and 119 (28). $v \mathrm{~cm}^{-1}(\mathrm{~K} \mathrm{Br}) 3260,2932,1638,1557,1448,1351$, 1300, 1252, 1119, 1056, 930 and 835. ${ }^{1} \mathrm{H}$ NMR $\left(\mathrm{CDCl}_{3}\right) \delta$ $0.96\left(3 \mathrm{H}, \mathrm{d}, J=6.5 \mathrm{~Hz}, \mathrm{CH}_{3}\right), 1.16-1.84(8 \mathrm{H}, \mathrm{bm}$, $\left.4 \times \mathrm{CH}_{2}\right), 2.16\left(2 \mathrm{H}, \mathrm{m},-\mathrm{CH}_{2}-\mathrm{CO}\right), 2.53(2 \mathrm{H}, \mathrm{t}, J=6.5 \mathrm{~Hz}$, $\left.\mathrm{Ar}-\mathrm{CH}_{2}\right), 3.30\left(2 \mathrm{H}, \mathrm{q}, J=6.5 \mathrm{~Hz},-\mathrm{NH}-\mathrm{CH}_{2}\right), 5.88(2 \mathrm{H}$, $\left.\mathrm{s},-\mathrm{O}-\mathrm{CH}_{2}-\mathrm{O}-\right)$ and $6.66(3 \mathrm{H}, \mathrm{m}, \mathrm{Ar}-\mathrm{H})$.

Preparation of 5-(3,4-methylenedioxy phenyl)pentanoic acid diethyl amide (17). The compound was prepared from tetrahydro piperic acid $\mathbf{5 h}(2.0 \mathrm{~g}, 9 \mathrm{mmol})$ and diethylamine $(1 \mathrm{~mL})$ by the method as described for $\mathbf{8}$, as a gummy mass $(2.30 \mathrm{~g}, 92 \%)$ (analysed for $\mathrm{C}_{16} \mathrm{H}_{23}$ $\mathrm{NO}_{3}$; found $\mathrm{C} 69.2879, \mathrm{H}$ 8.3590, N 5.0510; calcd C 69.2871, H 8.3579, N 5.0500). MS (\%) $\mathrm{M}^{+}$at $m / z 277$ (61), 205 (18), 175 (8), 134 (78), 127 (39), 114 (100), 99 (78) and 71(47). vem ${ }^{-1}(\mathrm{KBr}) 2957,1642,1553,1457$, 1361, 1241, 1128, 1053, 927 and 843. ${ }^{1} \mathrm{H} \mathrm{NMR}\left(\mathrm{CCl}_{4}\right) \delta$ : $1.13\left(3 \mathrm{H}, \mathrm{t}, J=6.5 \mathrm{~Hz},-\mathrm{CH}_{2}-\mathrm{CH}_{3}\right), 1.18(3 \mathrm{H}, \mathrm{t}, J=6.5 \mathrm{~Hz}$, $\left.-\mathrm{CH}_{2}-\mathrm{CH}_{3}\right), 1.79\left(4 \mathrm{H}, \mathrm{m},-\left(\overline{\mathrm{CH}_{2}}\right)_{2}-\right), 2.39(2 \mathrm{H}, \mathrm{t}, J=$ $\left.6.5 \mathrm{~Hz}, \quad \mathrm{CH}_{2}-\mathrm{CH}_{2}-\mathrm{CO}\right), \quad 2.69 \quad(2 \mathrm{H}, \quad \mathrm{t}, \quad J=6.5 \mathrm{~Hz}$, $\left.\mathrm{Ar}-\mathrm{CH}_{2}-\mathrm{CH}_{2}\right), 3.29\left(4 \mathrm{H}, \mathrm{q}, J=6.5 \mathrm{~Hz},-\mathrm{N}\left(\mathrm{CH}_{2}\right)_{2}\right), 5.86$ $\left(2 \mathrm{H}, \mathrm{s},-\mathrm{O}-\mathrm{CH}_{2}-\mathrm{O}-\right)$ and $6.59(3 \mathrm{H}, \mathrm{bs}, \mathrm{Ar}-\mathrm{H})$.

Preparation of $\alpha$-methyl-3,4-dimethoxy benzyl alcohol (2b). It was prepared from 3,4-dimethoxy benzaldehyde (1b) $(20 \mathrm{~g}, 100 \mathrm{mmol})$ and Grignard reagent $[\mathrm{Mg}$ metal, $3.0 \mathrm{~g}, 120 \mathrm{mmol})$ and methyl iodide $(9.0 \mathrm{~mL})$ as per the procedure described for compound 2a to give a gummy mass (2b) $(18.8 \mathrm{~g}, 90 \%)$, analysed for $\mathrm{C}_{10} \mathrm{H}_{14} \mathrm{O}_{3}$, MS (\%) $\mathrm{M}^{+}$at $m / z 182(60), 166(86), 164(5), 138$ (100), 123 (29), 107 (20) and 77 (23). vcm ${ }^{-1}(\mathrm{KBr}) 3476$, 2932, 1596, 1508, 1454, 1418, 1366, 1312, 1262, 1234, 136, 1018, 838, 756, and 720. ${ }^{1} \mathrm{H}$ NMR $\left(\mathrm{CDCl}_{3}\right) \delta 1.42$ $\left(3 \mathrm{H}, \quad \mathrm{d}, \quad J=7.0 \mathrm{~Hz},-\mathrm{CH}_{3}-\mathrm{CHOH}\right), \quad 3.84(6 \mathrm{H}, \quad \mathrm{s}$, $\left.2 \times \mathrm{OCH}_{3}\right), 4.74\left(1 \mathrm{H}, \mathrm{q}, J=7.0 \mathrm{~Hz}, \mathrm{CHOH}-\mathrm{CH}_{3}\right)$ and $6.88(3 \mathrm{H}, \mathrm{s}, \mathrm{Ar}-\mathrm{H})$.

Preparation of 3-(3,4-dimethoxyphenyl)-2E-propenal (3b). It was prepared from $2 \mathbf{b}(15.0 \mathrm{~g}, 80 \mathrm{mmol})$ and $\mathrm{POCl}_{3}$ $(14 \mathrm{~mL})$ and DMF $(40 \mathrm{~mL})$ as described for 3a to give crude product which on crystallisation from ethyl acetate:pet.ether (1:9) gave $3 \mathbf{b}(9.8 \mathrm{~g}, 63 \%), \mathrm{mp} 85^{\circ} \mathrm{C}$ (lit. mp $\left.81{ }^{\circ} \mathrm{C}\right)^{30}$ analysed for $\mathrm{C}_{11} \mathrm{H}_{12} \mathrm{O}_{3}$, MS $(\%) \mathrm{M}^{+}$at $\mathrm{m} / \mathrm{z}$ 192. $\mathrm{vcm}^{-1}(\mathrm{KBr}) 1705,1638,1595,1350,1135,1010$ and 830. ${ }^{1} \mathrm{H}$ NMR $\left(\mathrm{CDCl}_{3}\right) \delta 3.86\left(6 \mathrm{H}, \mathrm{s}, 2 \times \mathrm{OCH}_{3}\right)$ $6.56(1 \mathrm{H}, \mathrm{dd}, J=16.0 \mathrm{~Hz}$ and $7.0 \mathrm{~Hz},-\mathrm{CH}=\mathrm{CH}-\mathrm{CHO})$, $6.88-7.14(3 \mathrm{H}, \mathrm{m}, 3 \times \mathrm{Ar}-\mathrm{H}), 7.36(1 \mathrm{H}, \mathrm{d}, J=16.0 \mathrm{~Hz}$, $-\mathrm{CH}=\mathrm{CH}-\mathrm{CHO})$ and $9.65(1 \mathrm{H}, \mathrm{d}, J=7.0 \mathrm{~Hz},-\mathrm{CH}=$ $\mathrm{C} \overline{\mathrm{H}}-\mathrm{CHO}$ ).

Preparation of 5-(3,4-dimethoxy phenyl)-2E,4E-pentadienoic acid (4b). This compond was prepared from $\mathbf{3 b}$ $(9.0 \mathrm{~g}, 46 \mathrm{mmol})$ by Wittig reaction as described for $\mathbf{4 a}$ to give $\mathbf{4 b}(9.0 \mathrm{~g}, 83 \%)$, crystallised from ethylacetate, mp $166^{\circ} \mathrm{C}$ (lit. mp $\left.203-205^{\circ} \mathrm{C}\right)^{30}$ analysed for $\mathrm{C}_{13} \mathrm{H}_{14} \mathrm{O}_{4}$, MS (\%) $\mathrm{M}^{+}$at $m / z 234$ (87), 220 (19), 189 (100), 174 (56), 158 (38), 145 (19), 131 (32), 115 (66), 103 (52), 91 (74) and $77(41) . \mathrm{vcm}^{-1}(\mathrm{KBr}) 2936,1682,1628,1518$, $1444,1320,1212,1168,1140,1024,886$ and $827 .{ }^{1} \mathrm{H}$ NMR $\left(\mathrm{CDCl}_{3}\right) \delta 3.86\left(6 \mathrm{H}, \mathrm{s}, 2 \times \mathrm{OCH}_{3}\right), 5.92(1 \mathrm{H}, \mathrm{d}$, $J=15.0 \mathrm{~Hz},-\mathrm{CH}=\mathrm{CH}-\mathrm{CO}), 6.84-7.16(5 \mathrm{H}, \mathrm{m}$, olefinic and $\mathrm{Ar}-\mathrm{H})$ and $7.24-7.56(1 \mathrm{H}, \mathrm{m},-\mathrm{CH}-\mathrm{CH}=\mathrm{CH}-\mathrm{CO})$.

Preparation of 5-(3,4-dimethoxy phenyl)-2E, $4 E$-pentadienoic acid piperidine amide (18). Compound $4 \mathrm{~b}(2.0 \mathrm{~g}$, $8.5 \mathrm{mmol})$ was condensed with piperidine $(0.9 \mathrm{~mL})$ by the method described for compound 8 to yield $\mathbf{1 8}(2.40 \mathrm{~g}$, $91 \%$ ), a crystalline solid, mp $118^{\circ} \mathrm{C}$ (lit. mp $\left.110^{\circ} \mathrm{C}\right)^{25}$ (analysed for $\mathrm{C}_{18} \mathrm{C}_{23} \mathrm{NO}_{3}$; found $\mathrm{C} 71.7441, \mathrm{H} 7.6922$, N 4.6503; calcd C 71.7351, H 7.6917, N 4.6475). MS (\%) $\mathrm{M}^{+}$at $m / z 301$ (49), 217 (100), 159 (57), 114 (17) and 84 (16). $v \mathrm{~cm}^{-1}(\mathrm{KBr}) 2930,1635,1605,1565,1513,1452$, 1440, 1312, 1250, 11311025,870 and 808. ${ }^{1} \mathrm{H}$ NMR $\left(\mathrm{CDCl}_{3}\right) \delta 1.66\left(6 \mathrm{H}, \mathrm{bs}, \mathrm{N}-\left(\mathrm{CH}_{2}\right)_{2}-\left(\mathrm{CH}_{2}\right)_{3}\right), 3.59(4 \mathrm{H}$, bs, $-\mathrm{N}\left(\mathrm{CH}_{2}\right)_{2}, 3.92$ and $3.94\left(6 \mathrm{H}, 2 \times \mathrm{s}, 2 \times \mathrm{OCH}_{3}\right), 6.43$ $(1 \mathrm{H}, \mathrm{d}, J=15.0 \mathrm{~Hz},-\mathrm{CH}=\mathrm{CH}-\mathrm{CO}), 6.70-7.06(5 \mathrm{H}, \mathrm{m}$, olefinic and $\mathrm{Ar}-\mathrm{H})$ and $7.2 \overline{4}-7.75(1 \mathrm{H}, \mathrm{m}, \mathrm{CH}=\mathrm{CH}-$ $\mathrm{CH}=\mathrm{CH}-\mathrm{CO}$ ).

Preparation of 5-(3,4-dimethoxy phenyl)-2E,4E-pentadienoic acid pyrrolidine amide (19). Compound $4 \mathrm{~b}(2.0 \mathrm{~g}$, $8.5 \mathrm{mmol})$ was condensed with pyrrolidine $(0.9 \mathrm{~mL})$ as 
per the procedure described for $\mathbf{8}$ to furnish a crystalline solid $(2.25 \mathrm{~g}, 92 \%), \mathrm{mp} 148^{\circ} \mathrm{C}$ (analysed for $\mathrm{C}_{17} \mathrm{C}_{21} \mathrm{NO}_{3}$; found $\mathrm{C} 71.0803, \mathrm{H} 7.3666, \mathrm{~N} 4.8767$; calcd $\mathrm{C} 71.0569$, $\mathrm{H} 7.3657, \mathrm{~N} 4.8744) \mathrm{MS}(\%) . \mathrm{M}^{+}$at $m / z 287$ (41), 217 (100), 189 (66), 174 (22), 98 (37) and 70 (35). vcm ${ }^{-1}$ (KBr) $2965,1640,1605,1560,1514,1450,1322,1250$, 1020 , and 870. ${ }^{1} \mathrm{H}$ NMR $\left(\mathrm{CDCl}_{3}\right) \delta 1.85(4 \mathrm{H}, \mathrm{m}, \mathrm{N}-$ $\left.\mathrm{CH}_{2}-\left(\mathrm{CH}_{2}\right)_{2}\right), 3.46$ and $3.49(4 \mathrm{H}, 2 \times \mathrm{t}, J=6.0 \mathrm{~Hz}$, $\left.-\mathrm{N}\left(\mathrm{CH}_{2}\right)_{2}\right), 3.82$ and $3.86\left(6 \mathrm{H}, 2 \times \mathrm{s}, 2 \times \mathrm{OCH}_{3}\right), 6.18$ $(1 \mathrm{H}, \overline{\mathrm{d}}, J=15.0 \mathrm{~Hz},-\mathrm{CH}=\mathrm{CH}-\mathrm{CO}), 6.62-7.10(5 \mathrm{H}, \mathrm{m}$, olefinic and Ar-H) and 7.20-7.79 $(1 \mathrm{H}, \mathrm{m}, \mathrm{CH}=\mathrm{CH}-$ $\mathrm{CH}=\mathrm{CH}-\mathrm{CO}$ ).

Preparation of 5-(3,4-dimethoxy phenyl)-2E,4E-pentadienoic acid $n$-butyl amide (20). Compound $4 \mathbf{b}(1.5 \mathrm{~g}$, $6.4 \mathrm{mmol})$ was made to react with $n$-butylamine $(0.7 \mathrm{~mL})$ as per the procedure described for $\mathbf{8}$ to give $\mathbf{2 0}(1.6 \mathrm{~g}$, $86 \%$ ), a crystalline solid, $\mathrm{mp} 114{ }^{\circ} \mathrm{C}$ (analysed for $\mathrm{C}_{17} \mathrm{H}_{23} \mathrm{NO}_{3}$; found $\mathrm{C} 70.5704, \mathrm{H}$ 8.0119, $\mathrm{N}$ 4.8434; calcd C 70.5619, H 8.0110, N 4.8404). MS (\%) $\mathrm{M}^{+}$at m/z 289 (44), 217 (9), 189 (23), 188 (100), 157 (16), 151 (13), 99 (10) and 71 (38). vcm $\mathrm{cm}^{-1}(\mathrm{KBr}) 3240,2950,1650$, $1510,1450,1380,1250,1170,1025,1005$ and $870 .{ }^{1} \mathrm{H}$ NMR $\left(\mathrm{CDCl}_{3}\right) \delta 0.92\left(3 \mathrm{H}, \mathrm{t}, J=6.5 \mathrm{~Hz},-\mathrm{CH}_{2}-\mathrm{CH}_{3}\right)$, $1.46\left(4 \mathrm{H}, \mathrm{m},-\mathrm{NCH}_{2}-\left(\mathrm{CH}_{2}\right)_{2}\right), 3.31\left(2 \mathrm{H}, \mathrm{m},-\mathrm{NCH}_{2}\right.$ $\left.-\mathrm{CH}_{2}\right), 3.85\left(6 \mathrm{H}, \mathrm{s}, 2 \times \mathrm{OCH}_{3}\right), 5.94(1 \mathrm{H}, \mathrm{d}, J=14.0 \mathrm{~Hz}$, $-\mathrm{CH}=\mathrm{CH}-\mathrm{CO}), 6.62-7.00(5 \mathrm{H}, \mathrm{m}$, olefinic and $\mathrm{Ar}-\mathrm{H})$ and $7.1 \overline{7-7} .62(1 \mathrm{H}, \mathrm{m},=\mathrm{CH}-\mathrm{CH}=\mathrm{CH}-\mathrm{CO})$.

Preparation of 5-(3,4-dimethoxy phenyl)-2E,4E-pentadienoic acid- $n$-hexylamine amide (21). Compound 4 b $(1.5 \mathrm{~g}, 6.4 \mathrm{mmol})$ was condensed with $n$-hexylamine $(0.8 \mathrm{~mL})$ by the procedure described for $\mathbf{8}$ to give $\mathbf{2 1}$ $\left(1.8 \mathrm{~g}, 94 \%\right.$ ), a crystalline solid, $\mathrm{mp} 148^{\circ} \mathrm{C}$ (analysed for $\mathrm{C}_{19} \mathrm{H}_{27} \mathrm{NO}_{3}$; found $\mathrm{C}$ 71.9014, $\mathrm{H}$ 8.5740, N 4.4182; calcd C 71.8935, H 8.5731, N 4.4126). MS (\%) $\mathrm{M}^{+}$at $m / z 317$ (40.0), 217 (92.0), 189 (100), 159 (14.0), 114 (10.0), $89(15.0)$ and $63(13.0) \cdot \mathrm{vcm}^{-1}(\mathrm{KBr}) 3250,2950$, $2450,1650,1610,1510,1440,1260,1140,1020,990$ and $850 .{ }^{1} \mathrm{H}$ NMR $\left(\mathrm{CDCl}_{3}\right) \delta 0.90(3 \mathrm{H}, \mathrm{t}, J=6.5 \mathrm{~Hz}$, $\left.-\mathrm{CH}_{2}-\mathrm{CH}_{3}\right), 1.34-1.71\left(8 \mathrm{H}, \mathrm{m},\left(\mathrm{CH}_{2}\right)_{4}\right), 3.33(2 \mathrm{H}, \mathrm{m}$, $\left.-\mathrm{NH}-\mathrm{CH}_{2}\right), 3.94\left(6 \mathrm{H}, \quad \mathrm{s}, 2 \times \mathrm{OCH}_{3}\right), 5.97(1 \mathrm{H}, \mathrm{d}$, $J=14.0 \overline{\mathrm{Hz}},-\mathrm{CH}=\mathrm{CH}-\mathrm{CO}), 6.73-7.10(5 \mathrm{H}, \mathrm{m}$, olefinic and $\mathrm{Ar}-\mathrm{H})$ and $7.2 \overline{6(} 1 \mathrm{H}, \mathrm{m}, \mathrm{CH}-\mathrm{CH}=\mathrm{CH}-\mathrm{CO})$.

Preparation of 3,4-ethylenedioxy benzaldehyde (1c). To a solution of 3,4-dihydroxy benzaldehyde (6.9 g, $50 \mathrm{mmol})$, in dry acetone $(110 \mathrm{~mL})$ was added $1,2-$ dibromoethane $(6 \mathrm{~mL})$ and anhydrous potassium carbonate $(\mathbf{5 g})$ and the contents refluxed for $48 \mathrm{~h}$ to give after usual work up, 3,4-ethylenedioxy benzaldehyde (1c) $(7.5 \mathrm{~g}, 90 \%)$, crystallised from hexane:acetone, $\mathrm{mp}$ 54-55 ${ }^{\circ} \mathrm{C}$, analysed for $\mathrm{C}_{9} \mathrm{H}_{8} \mathrm{O}_{3}$, MS (\%) $\mathrm{M}^{+}$at $m / z 164$ (100) 135 (10) 119 (4) 91 (3) and 79 (22). vcm ${ }^{-1}(\mathrm{KBr})$ $1680,1608,1576,1500,1458,1394,1288,1206,1108$, 1040, 944, 910 and 862. ${ }^{1} \mathrm{H}$ NMR $\left(\mathrm{CDCl}_{3}\right) \delta: 4.24(4 \mathrm{H}$, s, $\left.-\mathrm{O}-\mathrm{CH}_{2}-\mathrm{CH}_{2}-\mathrm{O}-\right), 6.89(1 \mathrm{H}, \mathrm{d}, J=8.5 \mathrm{~Hz}, \mathrm{Ar}-\mathrm{H})$, $7.35(2 \mathrm{H}, \mathrm{m}, \mathrm{Ar}-\mathrm{H})$ and $9.71(1 \mathrm{H}, \mathrm{s}, \mathrm{CHO})$.

Preparation of $\alpha$-methyl-3,4-ethylenedioxy benzyl alcohol (2c). This compound was prepared from 3,4-ethylenedioxy benzaldehyde $(5.0 \mathrm{~g}, 30 \mathrm{mmol})$ and Grignard reagent (mg metal, $0.86 \mathrm{~g}, 36 \mathrm{mmol}$ ) and methyl iodide
$(4 \mathrm{~mL})$ in solvent ether $(80 \mathrm{~mL})$ by the procedure described for 2a to give a semisolid $(5.1 \mathrm{~g}, 94 \%$ ), analysed for $\mathrm{C}_{10} \mathrm{H}_{12} \mathrm{O}_{3}$, MS (\%) $\mathrm{M}^{+}$at $m / z 180(10), 164$ (100), $136(90), 106(66)$ and $92(90) \cdot \mathrm{vcm}^{-1}(\mathrm{KBr}) 3400$, $2968,1584,1500,1432,1284,1260,1198,1154,1054$, and $868 .{ }^{1} \mathrm{H}$ NMR $\left(\mathrm{CDCl}_{3}\right) \delta 1.44(3 \mathrm{H}, \mathrm{d}, J=7.0 \mathrm{~Hz}$, $\left.\mathrm{CH}_{3}\right), 4.21\left(4 \mathrm{H}, \quad \mathrm{s},-\mathrm{OCH}_{2}-\mathrm{CH}_{2} \mathrm{O}-\right), 4.76(1 \mathrm{H}, \quad \mathrm{q}$, $J=7.0 \mathrm{~Hz}, \mathrm{CHOH})$ and $6.96(3 \mathrm{H}, \mathrm{m}, 3 \times \mathrm{Ar}-\mathrm{H})$.

Preparation of 3-(3,4-ethylenedioxy phenyl)-2E-propenal (3c). It was prepared from $2 c(4.0 \mathrm{~g}, 22 \mathrm{mmol}), \mathrm{POCl}_{3}$ $(4 \mathrm{~mL})$ and DMF $(8 \mathrm{~mL})$ by the procedure described for 3a to give a yellow solid $(2.8 \mathrm{~g}, 67 \%), \mathrm{mp} 63-64^{\circ} \mathrm{C}$, analysed for $\mathrm{C}_{11} \mathrm{H}_{10} \mathrm{O}_{3}$, MS (\%) M + at $m / z 190$ (100), 162 (16), 134 (22), 106 (42) and $78(53) . v \mathrm{~cm}^{-1}(\mathrm{KBr})$ 2928,1668, 1612, 1576, 1502, 1452, 1436, 1394, 1288, 1202, 1112, 1036, 968, 912 and 876. ${ }^{1} \mathrm{H} \mathrm{NMR}\left(\mathrm{CDCl}_{3}\right) \delta$ $4.28\left(4 \mathrm{H}, \mathrm{s},-\mathrm{OCH}_{2} \mathrm{CH}_{2} \mathrm{O}-\right), 6.56(1 \mathrm{H}, \mathrm{dd}, J=15.0$ and $7.0 \mathrm{~Hz}, \mathrm{CH}=\mathrm{CH}-\mathrm{CHO}), 6.88-7.12(3 \mathrm{H}, \mathrm{m}, 3 \times \mathrm{Ar}-\mathrm{H})$, $7.36(1 \mathrm{H}, \mathrm{d}, \bar{J}=15.0 \mathrm{~Hz},-\mathrm{CH}=\mathrm{CH}-\mathrm{CHO})$ and 9.60 $(1 \mathrm{H}, \mathrm{d}, J=7.0 \mathrm{~Hz},=\mathrm{CH}-\mathrm{CHO})$.

Preparation of 5-(3,4-ethylenedioxy phenyl)-2E,4E-pentadienoic acid (4c). This compound was prepared from 3c $(4.0 \mathrm{~g}, 21 \mathrm{mmol})$ by the procedure described for $4 \mathbf{a}$ to furnish $4 \mathbf{c}(4.0 \mathrm{~g}, 82 \%), \mathrm{mp} 178-80^{\circ} \mathrm{C}$, analysed for $\mathrm{C}_{13} \mathrm{H}_{12} \mathrm{O}_{4}$, MS (\%) $\mathrm{M}^{+}$at $m / z$ 232. vcm ${ }^{-1}$ (KBr) 2968, $1704,1608,1582,1502,1462,1432,1374,1288,1256,1158$, 1054, 860 and $810 .{ }^{1} \mathrm{H}$ NMR $\left(\mathrm{CDCl}_{3}\right.$ and DMSO- $\left.d_{6}\right) \delta 4.28$ $\left(4 \mathrm{H}, \mathrm{s},-\mathrm{OCH}_{2} \mathrm{CH}_{2} \mathrm{O}-\right), 6.10(1 \mathrm{H}, \mathrm{d}, J=15.0 \mathrm{~Hz},-\mathrm{CH}=\mathrm{CH}-$ $\mathrm{CHO})$ and $6.72-7.60(6 \mathrm{H}, \mathrm{m}$, olefinic and $\mathrm{Ar}-\mathrm{H})$.

Preparation of 5-(3,4-ethylenedioxy phenyl)-2E,4E-pentadienoic acid piperidine amide (22). Compound $4 \mathrm{c}$ $(1.4 \mathrm{~g}, 6 \mathrm{mmol})$ was condensed with piperidine $(0.6 \mathrm{~mL})$ by the procedure described for $\mathbf{8}$ to yield $\mathbf{2 2}(1.4 \mathrm{~g}$, $78 \%$ ), mp $162{ }^{\circ} \mathrm{C}$ (analysed for $\mathrm{C}_{18} \mathrm{H}_{21} \mathrm{NO}_{3}$; found $\mathrm{C}$ 72.2207, H 7.0710, N 4.6813; calcd C 72.2181, H 7.0701, $\mathrm{N}$ 4.6788). MS (\%) $\mathrm{M}^{+}$at $m / z 299$ (62), 215 (90), 189 (100), $162(80), 114(31)$ and $84(80) \cdot \mathrm{vcm}^{-1}(\mathrm{KBr}) 2990$, $1630,1590,1500,1420,1300,1256,1150,990,926$ and 880. ${ }^{1} \mathrm{H}$ NMR $\left(\mathrm{CDCl}_{3}\right) \delta: 1.66\left(6 \mathrm{H}, \mathrm{m},-\mathrm{N}-\mathrm{C}-\left(\mathrm{CH}_{2}\right)_{3}\right)$, $3.60\left(4 \mathrm{H}, \mathrm{m},-\mathrm{N}-\left(\mathrm{CH}_{2}\right)_{2}\right), 4.26\left(4 \mathrm{H}, \mathrm{s},-\mathrm{OCH}_{2} \mathrm{CH}_{2} \mathrm{O}-\right)$, $6.17(1 \mathrm{H}, \mathrm{d}, J=14.0 \mathrm{~Hz},-\mathrm{CH}=\mathrm{CH}-\mathrm{CO}), 6.62-7.10$ $(5 \mathrm{H}, \mathrm{m}$, olefinic and $\mathrm{Ar}-\mathrm{H})$ and $\overline{7.29-7.79}(1 \mathrm{H}, \mathrm{m}$, $-\mathrm{C} \underline{\mathrm{H}}=\mathrm{CH}-\mathrm{CO})$.

Preparation of 5-(3,4-ethylenedioxy phenyl)- 2E,4E-pentadienoic acid pyrrolidine amide (23). Compound $4 \mathrm{c}$ $(1.6 \mathrm{~g}, 7 \mathrm{mmol})$ was reacted with pyrrolidine $(0.8 \mathrm{~mL})$ by the procedure described for 8 to yield $23(1.90 \mathrm{~g}, 95 \%)$, mp $113{ }^{\circ} \mathrm{C}$ (analysed for $\mathrm{C}_{17} \mathrm{H}_{19} \mathrm{NO}_{3}$ found $\mathrm{C} 71.5612$, H 6.7121, N 4.9101 calc. C 71.5589, H 6.7113, N 4.9088) MS (\%) M+ $\mathrm{M}^{+}$at $m / z 285$ (40), 215 (18), 188 (100), 98 (14) and $70(23) . v \mathrm{~cm}^{-1}(\mathrm{KBr}) 2960,1645,1600,1577,1510$, 1400, 1285, 1248, 1190, 1114, 1052 and $775 .{ }^{1} \mathrm{H} N M R$ $\left(\mathrm{CDCl}_{3}\right) \delta: 1.94\left(4 \mathrm{H}, \mathrm{m},-\mathrm{N}-\mathrm{C}-\left(\mathrm{CH}_{2}\right)_{2}\right), 3.57(4 \mathrm{H}, \mathrm{t}, J=$ $\left.7.0 \mathrm{~Hz}, \mathrm{~N}-\left(\mathrm{CH}_{2}\right)_{2}\right), 4.30\left(4 \mathrm{H}, \mathrm{s},-\mathrm{OCH}_{2} \mathrm{CH}_{2} \mathrm{O}-\right), 6.25(1 \mathrm{H}$, $\mathrm{d}, J=14.0 \mathrm{~Hz},-\mathrm{CH}=\mathrm{CH}-\mathrm{CO}), 6.7 \overline{3}-7.16(5 \mathrm{H}, \mathrm{m}$, Olefinic and $\mathrm{Ar}-\mathrm{H})$ and $7.30-7.70(1 \mathrm{H}, \mathrm{m},-\mathrm{CH}=\mathrm{CH}-\mathrm{CO})$.

Preparation of 4-benzyloxy-3-methoxy benzaldehyde (1d). To a solution of 4-hydroxy-3-methoxy benzaldehyde 
$(13.0 \mathrm{~g}, 85 \mathrm{mmol})$ in acetone $(250 \mathrm{~mL})$ was added benzylbromide $(12.0 \mathrm{~mL}, 88 \mathrm{mmol})$ and anhydrous potassium carbonate $(10 \mathrm{~g})$ and refluxed for $24 \mathrm{~h}$. The usual work up afforded 1d $(19.0 \mathrm{~g}, 92 \%), \operatorname{mp~} 67^{\circ} \mathrm{C}$, analysed for $\mathrm{C}_{15} \mathrm{H}_{14} \mathrm{O}_{3} \mathrm{MS}(\%) \mathrm{M}^{+}$at $m / z 242$ (100), 227 (18), 213 (21) 181 (29), and $91(50) \cdot \mathrm{vcm}^{-1}(\mathrm{KBr}) 2928,1674$, 1598, 1586, 1500, 1460, 1428, 1400, 1386, 1236, 1184, 1128, 916 and 818. ${ }^{1} \mathrm{H}$ NMR $\left(\mathrm{CDCl}_{3}\right) \delta: 4.12(3 \mathrm{H}, \mathrm{s}$, $\left.\mathrm{OCH}_{3}\right), \quad 5.44\left(2 \mathrm{H}, \quad \mathrm{s}, \quad-\mathrm{OCH}_{2}-\mathrm{Ar}\right), 7.20(1 \mathrm{H}, \mathrm{d}$, $J=8.5 \mathrm{~Hz}, \mathrm{Ar}-\mathrm{H}), 7.48-7.84(7 \mathrm{H}, \mathrm{m}, \mathrm{Ar}-\mathrm{H})$ and 9.92 (1H, s, Ar-CHO).

Peparation of $\alpha$-methyl-4-benzyloxy-3-methoxy benzyl alcohol (2d). It was prepared from 1d (14.5 g, $60 \mathrm{mmol})$ and magnesium iodide $(62 \mathrm{mmol})$ as described for $\mathbf{2 a}$ to furnish a semisolid $(14.0 \mathrm{~g}, 90 \%)$, analysed for $\mathrm{C}_{16} \mathrm{H}_{18} \mathrm{O}_{3}$, MS (\%) $\mathrm{M}^{+}$at $m / z 259$ (10), 241 (4), 151 (16), 121 (14) and 91 (100). vcm ${ }^{-1}(\mathrm{KBr}) 3410,2972$, $1594,1500,1454,1414,1382,1258,1222,1150,1115$ and 1072. ${ }^{1} \mathrm{H} \mathrm{NMR}\left(\mathrm{CDCl}_{3}\right) \delta 1.38(3 \mathrm{H}, \mathrm{d}, J=7.0 \mathrm{~Hz}$, $\left.\mathrm{CHOH}-\mathrm{CH}_{3}\right), 3.83\left(3 \mathrm{H}, \mathrm{s}, \mathrm{OCH}_{3}\right), 4.72(1 \mathrm{H}, \mathrm{q}, J=$ $\left.7.0 \mathrm{~Hz}, \mathrm{C} \overline{\mathrm{HOH}}-\mathrm{CH}_{3}\right), 5.04\left(2 \mathrm{H}, \mathrm{s}, \mathrm{Ar}-\mathrm{CH}_{2} \mathrm{O}\right), 6.76$ $(1 \mathrm{H}, \mathrm{s}, \mathrm{Ar}-\mathrm{H}), 6.82(2 \mathrm{H}, \mathrm{d}, J=8.5 \mathrm{~Hz}, 2 \times \mathrm{Ar}-\mathrm{H})$ and 7.16-7.52 (5H, m, 5× Ar-H).

Preparation of 3-(4-benzyloxy-3-methoxy phenyl)-2Epropenal (3d). This compound was prepared from 2d (11 g, $43 \mathrm{mmol})$ and Vilsmeier reagent as described for $\mathbf{3 a}$ to yield a crystalline solid $3 \mathbf{d}(7.0 \mathrm{~g}, 64 \%), \mathrm{mp} 91^{\circ} \mathrm{C}$ (lit. mp. $\left.90^{\circ} \mathrm{C}\right)^{31}$ analysed for $\mathrm{C}_{17} \mathrm{H}_{16} \mathrm{O}_{3}$, MS (\%) $\mathrm{M}^{+}$at $m / z$ 268 (51), 242 (23), 178 (41), 162 (9), 147 (20), 124 (10) and 91 (100). (KBr) 2940, 1666, 1620, 1598, 1502, 1480, 1460, 1426, 1384, 1260, 1220, 1168, 1120, 1028 and 972. ${ }^{1} \mathrm{H}$ NMR $\left(\mathrm{CDCl}_{3}\right) \delta 3.88\left(3 \mathrm{H}, \mathrm{s}, \mathrm{OCH}_{3}\right), 5.20\left(2 \mathrm{H}, \mathrm{s}, \mathrm{Ar}-\mathrm{CH}_{2} \mathrm{O}\right)$, $6.56(1 \mathrm{H}, \mathrm{dd}, J=15.0$ and $7.0 \mathrm{~Hz}, \mathrm{CH}=\mathrm{CH}-\mathrm{CHO}), 6.84$ $7.14(3 \mathrm{H}, \mathrm{m}, \mathrm{Ar}-\mathrm{H}), 7.22-7.54(6 \mathrm{H}, \mathrm{m}$, olefinic and $\mathrm{Ar}-\mathrm{H})$ and $9.60(1 \mathrm{H}, \mathrm{d}, J=7.0 \mathrm{~Hz},-\mathrm{CH}-\mathrm{CHO})$.

Preparation of 5-(4-benzyloxy-3-methoxyphenyl)-2E,4Epentadienoic acid (4d). This compound was prepared from 3d $(5.0 \mathrm{~g}, 19 \mathrm{mmol})$ by Wittig reaction as described for $\mathbf{4 a}$ to yield $\mathbf{4 d}(4.8 \mathrm{~g}, 81 \%)$, a crystalline solid, mp $196{ }^{\circ} \mathrm{C}$, analysed for $\mathrm{C}_{19} \mathrm{H}_{18} \mathrm{O}_{4}$, MS (\%) $\mathrm{M}^{+}$at $\mathrm{m} / z$ 310 (20), 297 (18), 266 (24), 219 (16), 175 (30) 115 (11) and $91(100) . \mathrm{vcm}^{-1}(\mathrm{KBr}) 2932,1666,1618,1592,1504$, 1454, 1422, 1352, 1308 and 1266. ${ }^{1} \mathrm{H} \mathrm{NMR}\left(\mathrm{CDCl}_{3}\right) \delta$ $3.90\left(3 \mathrm{H}, \mathrm{s}, \mathrm{OCH}_{3}\right), 5.14\left(2 \mathrm{H}, \mathrm{s}, \mathrm{Ar}-\mathrm{CH}_{2} \mathrm{O}\right), 5.92(1 \mathrm{H}$, $\mathrm{d}, \quad J=14.0 \mathrm{~Hz}, \quad \mathrm{CH}=\mathrm{CH}-\mathrm{CO}), \quad 6.73-7.10 \quad(5 \mathrm{H}, \quad \mathrm{m}$, $\mathrm{Ar}-\mathrm{H}), 7.21-7.70(6 \mathrm{H}, \overline{\mathrm{m}}$, olefinic and $\mathrm{Ar}-\mathrm{H})$.

Preparation of 5-(4-benzyloxy-3-methoxyphenyl)-2E,4Epentadienoic acid piperidine amide (24). Compound 4d $(1.55 \mathrm{~g}, 5 \mathrm{mmol})$ was condensed with piperidine $(0.6 \mathrm{~mL}$, $6 \mathrm{mmol})$ by the method described for 8 to furnish a solid $(1.8 \mathrm{~g}, 95 \%)$ crystallised from ethylacetate:pet.ether (9:1) to give a crystalline solid $\mathrm{mp} 116-17^{\circ} \mathrm{C}$ (lit. $\mathrm{mp}$. $118^{\circ} \mathrm{C}$ ) ${ }^{31}$ (analysed for $\mathrm{C}_{24} \mathrm{H}_{27} \mathrm{NO}_{3}$; found $\mathrm{C} 76.3667, \mathrm{H}$ 7.2103, N 3.7142; calcd C 76.3651, H 7.2091, N 3.7106); MS (\%) M+ at $m / z 377$ (42) 286 (100) 258 (12) 201 (13) and 91 (11). vcm ${ }^{-1}$ (KBr) 2928, 2856, 1620, 1510, 1450, $1390,1368,1266$ and $1196 .{ }^{1} \mathrm{H} \operatorname{NMR}\left(\mathrm{CDCl}_{3}\right) \delta: 1.50$ $\left(6 \mathrm{H}, \mathrm{bs}, 3 \times \mathrm{CH}_{2}\right), 3.44\left(4 \mathrm{H}, \mathrm{bs},-\mathrm{N}\left(\mathrm{CH}_{2}\right)_{2}\right), 3.98(3 \mathrm{H}, \mathrm{s}$, $\left.\mathrm{OCH}_{3}\right) 5.04\left(2 \mathrm{H}, \mathrm{s}, \mathrm{Ar}-\mathrm{CH}_{2}\right), 6.34(1 \mathrm{H}, \mathrm{d}, J=15 \mathrm{~Hz}$,
$\mathrm{CO}-\mathrm{CH}=\mathrm{CH}), 6.84-7.00(6 \mathrm{H}, \mathrm{m}$, olefinic and $\mathrm{Ar}-\mathrm{H})$ and $7 . \overline{28}-7.78(5 \mathrm{H}$, bs, olefinic and $\mathrm{Ar}-\mathrm{H})$.

Preparation of 5-(4-benzyloxy-3-methox phenyl)-2E,4Epentadienoic acid pyrrolidine amide (25). Compound 4d $(1.55 \mathrm{~g}, 5 \mathrm{mmol})$ was condensed with pyrrolidine $(0.6 \mathrm{~mL})$ by the method described for $\mathbf{8}$ to yield $\mathbf{2 5}$ $\left(1.7 \mathrm{~g}, 94 \%\right.$ ), mp $155^{\circ} \mathrm{C}$ (analysed for $\mathrm{C}_{23} \mathrm{H}_{25} \mathrm{NO}_{3}$; found C 76.0120, H 6.9336, N 3.8551; calcd C 76.0075, H 6.9327, $\mathrm{N} 3.8538)$. MS (\%) $\mathrm{M}^{+}$at $m / z 363$ (19), 273 (44), 244 (5), 201 (17), 155 (3), 145 (4), 131 (6), 115 (14) and 91 (100). $\mathrm{vcm}^{-1}(\mathrm{KBr}) 2914,1636,1610,1589,1504,1420,1384$, 1354, 1260, 12301138 and 980. ${ }^{1} \mathrm{H} \mathrm{NMR}\left(\mathrm{CDCl}_{3}\right) \delta: 1.90$ (4H, bs, $\left.-\mathrm{N}-\mathrm{C}-\left(\mathrm{CH}_{2}\right)_{2}\right), 3.52\left(4 \mathrm{H}, \mathrm{bs},-\mathrm{N}-\left(\mathrm{CH}_{2}\right)_{2}-\right), 3.88$ $\left(3 \mathrm{H}, \mathrm{s}, \mathrm{OCH}_{3}\right), 5 . \overline{14}\left(2 \mathrm{H}, \mathrm{s}, \mathrm{Ar}-\mathrm{CH}_{2} \mathrm{O}\right), 6 . \overline{24}(1 \mathrm{H}, \mathrm{d}$, $J=15.0 \mathrm{~Hz},-\mathrm{CH}=\mathrm{CH}-\mathrm{CO}), 6.68-7.08(5 \mathrm{H}, \mathrm{m}$, olefinic and $\mathrm{Ar}-\mathrm{H})$ and 7.16-7.80 (6H, m, olefinic and $\mathrm{Ar}-\mathrm{H})$.

Preparation of 5-(4-benzyloxy-3-methoxy phenyl)-2E,4Epentadienoic acid isobutyl amide (26). Compound 4d $(1.55 \mathrm{~g}, 5 \mathrm{mmol})$ was condensed with isobutyl amine $(0.6 \mathrm{~mL})$ by the method described for 8 to furnish a solid (1.65 g, 90\%), mp $183^{\circ} \mathrm{C}$ (analysed for $\mathrm{C}_{23} \mathrm{H}_{27} \mathrm{NO}_{3}$; found $\mathrm{C} 75.5910, \mathrm{H} 7.4472, \mathrm{~N} 3.8347$; calcd C 75.5883, $\mathrm{H}$ 7.4461, N 3.8325). MS (\%) $\mathrm{M}^{+}$at $m / z 365$ (14), 293 (3), 274 (34), 201 (18), 175 (17), 143 (12), 131 (6), 115 (17) and $91(100) . \mathrm{vcm}^{-1}(\mathrm{KBr}) 2956,1642,1610,1594$, 1512, 1458, 1414, 1332, 1248, 1234 and 1122. ${ }^{1} \mathrm{H}$ NMR $\left(\mathrm{CDCl}_{3}\right): 0.92\left(6 \mathrm{H}, \mathrm{d}, J=6.5 \mathrm{~Hz},-\mathrm{CH}-\left(\mathrm{CH}_{3}\right)_{2}\right), 1.80$ $\left(1 \mathrm{H}, \mathrm{m}, \mathrm{CH}-\left(\mathrm{CH}_{3}\right)_{2}\right), 3.20\left(2 \mathrm{H}, \mathrm{t}, J=6.5 \mathrm{~Hz},-\overline{\mathrm{NH}}-\mathrm{CH}_{2}\right)$, $3.90\left(3 \mathrm{H}, \mathrm{s}, \mathrm{OCH}_{3}\right), 5.20\left(2 \mathrm{H}, \mathrm{s}, \mathrm{Ar}-\mathrm{CH}_{2} \mathrm{O}\right), 5.94 \overline{(1 \mathrm{H}}$, $\mathrm{d}, J=14.0 \mathrm{~Hz},-\mathrm{CH}=\mathrm{CH}-\mathrm{CO}), 6.70-7.08(5 \mathrm{H}, \mathrm{m}$, olefinic and $\mathrm{Ar}-\mathrm{H})$. and 7.24-7.80 (6H, m, olefinic and $\mathrm{Ar}-\mathrm{H}$.)

Preparation of $\alpha$-methyl-3,4,5-trimethoxy benzyl alcohol (2e). This compound was prepared from 3,4,5-trimethoxy benzaldehyde $1 \mathrm{e}(10.0 \mathrm{~g}, 51 \mathrm{mmol})$ by reacting with methyl magnesium iodide $(53 \mathrm{mmol})$ as described for 2a to yield a semisolid 2e $(9.80 \mathrm{~g}, 90 \%)$ analysed for $\mathrm{C}_{11} \mathrm{H}_{16} \mathrm{O}_{4}$, MS (\%) $\mathrm{M}^{+}$at $m / z 212$ (100), 196 (52), 168 (80), 153 (31), 137 (32), 122 (11), 108 (13), 94 (13) and 77 (13). vcm ${ }^{-1}(\mathrm{KBr}) 3480,2972,1594$, 1502, 1456, 1420,1328, 1234, 1118, 1000 and $832 .{ }^{1} \mathrm{H}$ $\operatorname{NMR}\left(\mathrm{CDCl}_{3}\right) \delta 1.44\left(3 \mathrm{H}, \mathrm{d}, J=7.0 \mathrm{~Hz}, \mathrm{CH}_{3}-\mathrm{CHOH}\right)$, $3.76\left(3 \mathrm{H}, \mathrm{s}, \mathrm{OCH}_{3}\right), 3.82\left(6 \mathrm{H}, \mathrm{s}, 2 \times \mathrm{OCH}_{3}\right), 4.76(1 \mathrm{H}, \mathrm{q}$, $\left.J=7.0 \mathrm{~Hz}, \mathrm{CHOH}-\mathrm{CH}_{3}\right)$ and $6.56(2 \mathrm{H}, \mathrm{s}, 2 \times \mathrm{Ar}-\mathrm{H})$.

Preparation of 3-(3,4,5-trimethoxy phenyl-2E-propenal (3e). This compound was prepared from 2e $(8.5 \mathrm{~g}$, $40 \mathrm{mmol})$ by reacting with Vilsmeier reagent as described for $\mathbf{3 a}$ to give a yellow crystalline solid $(5.9 \mathrm{~g}$, $66 \%)$, mp $110-111^{\circ} \mathrm{C}^{32}$ analysed for $\mathrm{C}_{12} \mathrm{H}_{14} \mathrm{O}_{4}$. MS (\%) $\mathrm{M}^{+}$at $m / z 222,207,179$ and 151. $\mathrm{vcm}^{-1}(\mathrm{KBr}) 1695$, 1638, 1595, 1570, 1350, 1135, 1010 and $830{ }^{1} \mathrm{H}$ NMR $\left(\mathrm{CDCl}_{3}\right) \delta 3.88\left(9 \mathrm{H}, \mathrm{s}, 3 \times \mathrm{OCH}_{3}\right), 6.46(1 \mathrm{H}, \mathrm{dd}$, $J=16.0 \mathrm{~Hz}$ and $7.0 \mathrm{~Hz},-\mathrm{CH}=\mathrm{CH}-\mathrm{CHO}), 6.80(2 \mathrm{H}, \mathrm{bs}$, $2 \times \mathrm{Ar}-\mathrm{H}), 7.40(1 \mathrm{H}, \mathrm{d}, J=16.0 \mathrm{~Hz}, \mathrm{CH}=\mathrm{CH}-\mathrm{CHO})$ and $9.70(1 \mathrm{H}, \mathrm{d}, J=7.0 \mathrm{~Hz},=\mathrm{CH}-\mathrm{CHO})$.

Preparation of 5-(3,4,5-trimethoxy phenyl)-2E,4E-pentadienoic acid (4e). This compound was prepared from 3e $(5.1 \mathrm{~g}, 23 \mathrm{mmol})$ through Wittig reaction as described for $\mathbf{4 a}$ to give $(4.6 \mathrm{~g}, 76 \%)$, mp $190{ }^{\circ} \mathrm{C}^{33}$ analysed 
for $\mathrm{C}_{14} \mathrm{H}_{16} \mathrm{O}_{5} \mathrm{MS}(\%) \mathrm{M}+$ at $m / z 264 v \mathrm{~cm}^{-1}(\mathrm{KBr})$ $2932,1700,1626,1605,1506,1424,1338,1232,1160$, 1120, 1010, 974 and 846. ${ }^{1} \mathrm{H} \mathrm{NMR}\left(\mathrm{CDCl}_{3}\right) \delta: 3.81(9 \mathrm{H}$, $\left.\mathrm{s}, 3 \times \mathrm{OCH}_{3}\right), 6.20(1 \mathrm{H}, \mathrm{d}, J=15.0 \mathrm{~Hz},-\mathrm{CH}=\mathrm{CH}-\mathrm{CO})$, 6.70-7.10 (4H, m, olefinic and $\mathrm{Ar}-\mathrm{H})$, and 7.30-7.84 (1H, m, $\mathrm{CH}-\mathrm{CH}-\mathrm{CO})$.

Preparation of 5-(3,4,5-trimethoxy phenyl)-2E,4E-pentadienoic acid piperidine amide (27). Compound $4 \mathrm{e}(1.6 \mathrm{~g}$, $6 \mathrm{mmol})$ was condensed with piperidine $(0.5 \mathrm{~mL})$ as described for 6 to furnish $27(1.86 \mathrm{~g}, 94 \%), \mathrm{mp} 214^{\circ} \mathrm{C}$ (analysed for $\mathrm{C}_{19} \mathrm{H}_{25} \mathrm{NO}_{4}$; found $\mathrm{C} 68.8644, \mathrm{H} 7.6040, \mathrm{~N}$ 4.2296; calcd C 68.8601, H 7.6031, N 4.2264). MS (\%) $\mathrm{M}^{+}$ at $m / z 331$ (37), 277 (70), 247 (14), 219 (23), 189 (12), 112 (11) and 84 (100). vcm $\mathrm{cm}^{-1}(\mathrm{KBr}) 2930,1640,1605,1560$, 1440, 1350, 1250, 1140, 1010, 960 and 870. ${ }^{1} \mathrm{H}$ NMR $\left(\mathrm{CDCl}_{3}\right) \delta: 1.60\left(6 \mathrm{H}, \mathrm{bs},-\mathrm{N}-\mathrm{C}-\left(\mathrm{CH}_{2}\right)_{3}\right), 3.62(4 \mathrm{H}, \mathrm{m}, \mathrm{N}$ $\left.\left(\mathrm{CH}_{2}\right)_{2}\right), 3.89\left(3 \mathrm{H}, \mathrm{s}, \mathrm{OCH}_{3}\right), 3.94\left(6 \mathrm{H}, \mathrm{s}, 2 \times \mathrm{OCH}_{3}\right), 6.47$ $(1 \mathrm{H}, \mathrm{d}, J=15.0 \mathrm{~Hz}, \mathrm{CH}=\mathrm{CH}-\mathrm{CO}), 6.66-7.00(4 \mathrm{H}$, m, olefinic and $\mathrm{Ar}-\mathrm{H})$ and $7.23-\overline{7.72}(1 \mathrm{H}, \mathrm{m},-\mathrm{CH}=\mathrm{CH}-\mathrm{CO})$.

Preparation of 5-(3,4,5-trimethoxy phenyl)-2E,4E-pentadienoic acid pyrrolidine amide (28). Compound $4 \mathrm{e}(1.6 \mathrm{~g}$, $6 \mathrm{mmol})$ was condensed with pyrrolidine $(0.6 \mathrm{~mL})$ as described for $\mathbf{8}$ to yield $\mathbf{2 8}(1.80 \mathrm{~g}, 95 \%)$, a crystalline solid, mp $190{ }^{\circ} \mathrm{C}$ (analysed for $\mathrm{C}_{18} \mathrm{H}_{23} \mathrm{NO}_{4}$; found $\mathrm{C} 68.1212, \mathrm{H}$ 7.3047, N 4.4150; calcd C 68.1190, H 7.3040, N 4.4132). MS (\%) $\mathrm{M}^{+}$at $m / z 317$ (57), 219 (100), 189 (63), 159 (12), 98 (35), 70 (16). vcm $\mathrm{cm}^{-1}$ (KBr) 2960, 1640, 1605, 1560, 1450, 1330, 1250, 1135, 1015, 970 and 860. ${ }^{1} \mathrm{H} \mathrm{NMR}\left(\mathrm{CDCl}_{3}\right) \delta$ $1.95\left(4 \mathrm{H}, \mathrm{m}, \mathrm{N}-\mathrm{C}-\left(\mathrm{CH}_{2}\right)_{2}\right), 3.64(4 \mathrm{H}, \mathrm{t}, J=6.5 \mathrm{~Hz}$, $\left.-\mathrm{N}\left(\mathrm{CH}_{2}\right)_{2}\right), 3.85\left(3 \mathrm{H}, \mathrm{s}, \mathrm{OCH}_{3}\right), 3.92\left(6 \mathrm{H}, \mathrm{s}, 2 \times \mathrm{OCH}_{3}\right), 6.26$ $(1 \mathrm{H}, \mathrm{d}, J=15.0 \mathrm{~Hz}, \mathrm{CH}=\mathrm{CH}-\mathrm{CO}), 6.65-6.93$ (4H, m, olefinic and $\mathrm{Ar}-\mathrm{H})$ and $7.23-\overline{7.60}(1 \mathrm{H}, \mathrm{m},-\mathrm{CH}=\mathrm{CH}-\mathrm{CO})$.

Preparation of (2H)-2,2-dimethyl-3,4-dihydro-6-formyl benzopyran (1g). To a stirring solution of 4-hydroxy benzaldehyde 1f $(25 \mathrm{~g}, 205 \mathrm{mmol})$ and orthophosphoric acid $(20 \mathrm{~mL})$ in hexane $(200 \mathrm{~mL})$, a slow addition of freshly distilled isoprene $(25 \mathrm{~mL})$ in $n$-hexane $(40 \mathrm{~mL})$ was made in $9 \mathrm{~h}$ at room temperature and the reaction mixture stirred further for $24 \mathrm{~h}$. The reaction mixture was worked up by dilution with water, followed by extraction of the aqueous layer with solvent ether $(2 \times 100 \mathrm{~mL})$. The combined organic layer washed with water, dried over anhydrous sodium sulfate and concentrated to give crude resinous product which on $\mathrm{CC}$ over $\mathrm{SiO}_{2}$ and elution with hexane:benzene (4:1) afforded $1 \mathrm{~g}(11.5 \mathrm{~g}, 30 \%)$, as a gummy mass ${ }^{34}$ analysed for $\mathrm{C}_{12} \mathrm{H}_{14} \mathrm{O}_{2}$, MS (\%) $\mathrm{M}^{+}$at $m / z 190$ (36), 189 (73), 160 (33), 146 (38), 134 (100) and 106 (13). vcm ${ }^{-1}(\mathrm{KBr}) 2940$, $1682,1606,1576,1488,1432,1384,1362,1352,1324$, $1270,1236,1114,1108,874$ and $818 .{ }^{1} \mathrm{H} \mathrm{NMR}\left(\mathrm{CDCl}_{3}\right)$ $\delta: 1.35\left(6 \mathrm{H}, \mathrm{bs},-\mathrm{C}\left(\mathrm{CH}_{3}\right)_{2}\right), 1.85(2 \mathrm{H}, \mathrm{t}, J=6.0 \mathrm{~Hz}$, $\left.-\mathrm{CH}_{2}-\mathrm{CH}_{2}-\mathrm{Ar}\right), 2.85\left(2 \mathrm{H}, \mathrm{t}, J=6.0 \mathrm{~Hz}, \mathrm{Ar}-\mathrm{CH}_{2}-\right.$ $\left.\mathrm{CH}_{2}\right), 6.87(1 \mathrm{H}, \mathrm{d}, J=8.5 \mathrm{~Hz}, \mathrm{Ar}-\mathrm{H}), 7.64(2 \mathrm{H}, \mathrm{bs}$, $\mathrm{Ar}-\mathrm{H})$ and $9.80(1 \mathrm{H}, \mathrm{s}, \mathrm{Ar}-\mathrm{CHO})$.

Preparation of 1-[-(2H)-2,2-dimethyl-3,4-dihydro-benzopyran-6yl]-ethanol (2g). This compound was prepared from $1 \mathrm{~g}(7.0 \mathrm{~g}, 37 \mathrm{mmol})$ and methyl magnesium iodide $(39 \mathrm{mmol})$ reagent by the method as described for $\mathbf{2 a}$ to give $2 \mathrm{~g}(7.3 \mathrm{~g}, 94 \%)$ a semisolid, analysed for $\mathrm{C}_{13} \mathrm{H}_{18} \mathrm{O}_{2}$,
MS (\%) $\mathrm{M}^{+}+1$ at $m / z 207(48), 188(100), 121(80)$ and 96 (61). vcm ${ }^{-1}(\mathrm{KBr}) 3352,2932,1618,1588,1494,1450$, $1370,1348,1252,1208,1150,1120,1070,926$ and $878 .{ }^{1} \mathrm{H}$ NMR $\left(\mathrm{CDCl}_{3}\right) \delta 1.28\left(6 \mathrm{H}, \mathrm{s},\left(\mathrm{CH}_{3}\right)_{2}\right), 1.44(3 \mathrm{H}, \mathrm{d}$, $\left.J=6.5 \mathrm{~Hz}, \quad \mathrm{CH}_{3}-\mathrm{CHOH}\right), \quad 1.76 \quad(2 \mathrm{H}, \quad \mathrm{t}, \quad J=7.0 \mathrm{~Hz}$, $\left.\mathrm{Ar}-\mathrm{CH}_{2}-\mathrm{CH}_{2}\right), 2.76\left(2 \mathrm{H}, \mathrm{t}, J=7.0 \mathrm{~Hz}, \mathrm{Ar}-\mathrm{CH}_{2}-\mathrm{CH}_{2}\right)$, $4.76\left(1 \mathrm{H}, \mathrm{q}, J=6.5 \mathrm{~Hz}, \mathrm{CHOH}-\mathrm{CH}_{3}\right) 6.7 \overline{2}(1 \mathrm{H}, \mathrm{d}$, $J=8.5 \mathrm{~Hz}, \mathrm{Ar}-\mathrm{H})$ and $7.04(\overline{2 \mathrm{H}}, \mathrm{bs}, \mathrm{Ar}-\mathrm{H})$.

Preparation of 3-[(2H)-2,2-dimethyl-3,4-dihydro-benzopyran-6yl]-2-propenal (3g). This compound was prepared from $2 \mathrm{~g}(6.20 \mathrm{~g}, 30 \mathrm{mmol})$ and Vilsmeier reagent by the method as described for $\mathbf{3 a}$ to give $\mathbf{3 g}(4.2 \mathrm{~g}, 65 \%)$, a semi solid, analysed for $\mathrm{C}_{14} \mathrm{H}_{16} \mathrm{O}_{2}$, MS (\%) $\mathrm{M}^{+}$at $m / z$ $216(33), 188(30), 174(28), 160(48), 146(31), 103$ (40) and $69(100) . v \mathrm{~cm}^{-1}(\mathrm{KBr}) 2968,2916,1664,1606,1574,1492$, 1426, 1386, 1365, 1336, 1244, 1106, 944 and 800. ${ }^{1} \mathrm{H}$ NMR $\left(\mathrm{CDCl}_{3}\right) \delta 1.24\left(6 \mathrm{H}, \mathrm{s}, \mathrm{C}\left(\mathrm{CH}_{3}\right)_{2}\right), 1.76(2 \mathrm{H}, \mathrm{t}, J=7.0 \mathrm{~Hz}$, $\left.\mathrm{Ar}-\mathrm{CH}_{2}-\mathrm{CH}_{2}\right), 2.72\left(2 \mathrm{H}, \mathrm{t}, J=7.0 \mathrm{~Hz}, \mathrm{Ar}-\mathrm{CH}_{2}-\mathrm{CH}_{2}\right)$, $6.48(1 \mathrm{H}, \mathrm{dd}, J=14.0$ and $7.0 \mathrm{~Hz}, \mathrm{CH}=\mathrm{CH}-\overline{\mathrm{CHO}}), 6.74$ $(1 \mathrm{H}, \mathrm{d}, J=8.5 \mathrm{~Hz}, \mathrm{Ar}-\mathrm{H}), 7.20(2 \mathrm{H}, \mathrm{bs}, \overline{2} \times \mathrm{Ar}-\mathrm{H}), 7.32$ $(1 \mathrm{H}, \mathrm{d}, J=15.0 \mathrm{~Hz}, \mathrm{Ar}-\mathrm{CH}=\mathrm{CH}-\mathrm{CHO})$ and $9.56(1 \mathrm{H}, \mathrm{d}$, $J=7.0 \mathrm{~Hz}, \mathrm{Ar}-\mathrm{CHO})$.

Preparation of 5-[(2H)-2,2-dimethyl-3,4-dihydro-benzopyran-6yll-2 $E, 4 E$-pentadienoic acid (4g). This compound was prepared from $3 \mathrm{~g}(3.90 \mathrm{~g}, 18 \mathrm{mmol})$ by Wittig reaction as described for $\mathbf{4 a}$ to give [ $4.1 \mathrm{~g}, 89 \%$ ], a crystalline solid, mp $217^{\circ} \mathrm{C}$, analysed for $\mathrm{C}_{16} \mathrm{H}_{18} \mathrm{O}_{3}$, MS (\%) M ${ }^{+}$at $m / z 258$ (57), 213 (19), 203 (26), 171 (10), 157 (100), 145 (26), $129(82), 115(54), 102$ (13) and $91(33) \cdot \mathrm{vcm}^{-1}(\mathrm{KBr})$ 2944, 1644, 1598, 1494, 1408, 1388, 1362, 1214, 1120, 970 and 866. ${ }^{1} \mathrm{H}$ NMR $\left(\mathrm{CD}_{3} \mathrm{OD}\right) \delta 1.46\left(6 \mathrm{H}, \mathrm{s}, \mathrm{C}\left(\mathrm{CH}_{3}\right)_{2}\right), 1.90$ $\left(2 \mathrm{H}, \mathrm{t}, J=7.0 \mathrm{~Hz}, \mathrm{Ar}-\mathrm{CH}_{2}-\mathrm{CH}_{2}\right), 2.87(2 \mathrm{H}, \mathrm{t}, J=7.0 \mathrm{~Hz}$, $\left.\mathrm{Ar}-\mathrm{CH}_{2}-\mathrm{CH}_{2}\right), 5.95(1 \mathrm{H}, \mathrm{d}, J=15.0 \mathrm{~Hz}, \mathrm{CH}=\mathrm{CH}-$ $\mathrm{CO}), \overline{6.53}-7.00(5 \mathrm{H}, \mathrm{m}$, olefinic and $\mathrm{Ar}-\mathrm{H})$ and $7.43-\overline{7.80}$ $(1 \mathrm{H}, \mathrm{m}, \mathrm{CH}=\mathrm{CH}-\mathrm{CHO})$.

Preparation of 5-(2H)-2,2-dimethyl-3,4-dihydro-benzopyran-6yl-2 $E, 4 E$-pentadienoic acid piperidine amide (29). Compound $\mathbf{4 g}(1.0 \mathrm{~g}, 4 \mathrm{mmol})$ was condensed with piperidine $(0.6 \mathrm{~mL})$ as described for 8 to yield $29(1.16 \mathrm{~g}$, $89 \%$ ), mp $164{ }^{\circ} \mathrm{C}$ (analysed for $\mathrm{C}_{21} \mathrm{H}_{27} \mathrm{NO}_{2}$; found $\mathrm{C}$ 77.5093, H 8.3624, N 4.3055; calcd C 77.5023, H 8.3617, N 4.3038) MS (\%) $\mathrm{M}^{+}$at $m / z 325$ (85), 297 (37), 241 (100),

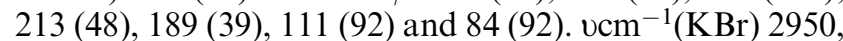
$1650,1610,1548,1447,1383,1314,1010,972$ and $865 .{ }^{1} \mathrm{H}$ NMR $\left(\mathrm{CDCl}_{3}\right) \delta 1.34\left(6 \mathrm{H}, \mathrm{bs},-\mathrm{C}-\left(\mathrm{CH}_{3}\right)_{2}\right), 1.59-2.16$ $\left(6 \mathrm{H}, \mathrm{m}, \mathrm{N}-\left(\mathrm{CH}_{2}\right)_{3}\right), 1.80\left(2 \mathrm{H}, \mathrm{t}, J=6 \mathrm{~Hz}, \mathrm{Ar}-\mathrm{C}-\mathrm{CH}_{2}\right)$, $2.72\left(2 \mathrm{H}, \mathrm{t}, \quad J=6.0 \mathrm{~Hz}, \quad \mathrm{Ar}-\mathrm{CH}_{2}\right), 3.52(4 \overline{\mathrm{H},} \mathrm{m}$, $\left.-\mathrm{N}-\left(\mathrm{CH}_{2}\right)_{2}\right), 6.16(1 \mathrm{H}, \mathrm{d}, J=14.0 \mathrm{~Hz},-\mathrm{CH}=\mathrm{CH}-\mathrm{CO})$, 6.59-6.82 and 6.92-7.69 (6H, m, olefinic and $\mathrm{Ar}-\overline{\mathrm{H}})$.

Preparation of 5-[(2H)-2,2-dimethyl-3,4-dihydrobenzopyran-6yl -2 $E, 4 E$-pentadienoic acid pyrrolidine amide (30). Compound 4g (1.0 g, $4 \mathrm{mmol})$ was condensed with pyrrolidine $(0.5 \mathrm{~mL})$ as described for the $\mathbf{8}$ to give $\mathbf{3 0}$ $(0.98 \mathrm{~g}, 85 \%), \mathrm{mp} 117^{\circ} \mathrm{C}$ (analysed for $\mathrm{C}_{20} \mathrm{H}_{25} \mathrm{NO}_{2}$, found $\mathrm{C} 77.1400, \mathrm{H} 8.0917, \mathrm{~N} 4.5004$, calcd $\mathrm{C} 77.1363$, $\mathrm{H} 8.0910, \mathrm{~N} 4.4977) \mathrm{MS}(\%) \mathrm{M}^{+}$at $m / z 311(73), 241$ (100), $184(50), 158$ (40), 127 (31), 97 (31) and 70 (46). $\mathrm{vcm}^{-1}$ (KBr) 2972, 1653, 1610, 1540, 1450, 1385, 1364, 1320, 1250, 1040, 972 and 865. ${ }^{1} \mathrm{H} \mathrm{NMR}\left(\mathrm{CDCl}_{3}\right) \delta 1.32$ 
$\left(6 \mathrm{H}, \mathrm{s},-\mathrm{C}-\left(\mathrm{CH}_{3}\right)_{2}\right), 1.62\left(4 \mathrm{H}, \mathrm{m}, 2 \times \mathrm{CH}_{2}\right), 1.80(2 \mathrm{H}, \mathrm{t}$, $\left.J=6.5 \mathrm{~Hz}, \mathrm{Ar}-\mathrm{CH}_{2}-\mathrm{CH}_{2}\right), 2.75(2 \mathrm{H}, \mathrm{t}, J=6.5 \mathrm{~Hz}, \mathrm{Ar}-$ $\left.\mathrm{CH}_{2}-\mathrm{CH}_{2}\right), 3.58\left(2 \mathrm{H}, \mathrm{m},-\mathrm{N}-\left(\mathrm{CH}_{2}\right)_{2}\right), 6.40(1 \mathrm{H}, \mathrm{d}$, $J=14.0 \mathrm{~Hz},-\mathrm{CH}=\mathrm{CH}-\mathrm{CO}), 6.60-6.92(3 \mathrm{H}, \mathrm{m}$, olefinic and $\mathrm{Ar}-\mathrm{H})$ and $7.04-7.68(3 \mathrm{H}, \mathrm{m}$, olefinic and $\mathrm{Ar}-\mathrm{H})$

Preparation of 5-[(2H)-2,2-dimethyl-3,4-dihydrobenzopyran-6yll-2E,4E-pentadienoic acid $n$-pentyl amide (31). Compound $4 \mathrm{~g}(1.0 \mathrm{~g}, 4 \mathrm{mmol})$ was condensed with $n$ pentyl amine $(0.6 \mathrm{~mL})$ as described for $\mathbf{8}$ to yield $\mathbf{3 1}$, a solid $(1.20 \mathrm{~g}, 92 \%), \mathrm{mp} 137^{\circ} \mathrm{C}$ (analysed for $\mathrm{C}_{21} \mathrm{H}_{29} \mathrm{NO}_{2}$; found C 77.0317, H 8.9267, N 4.2793; calcd C 77.0253, H 8.9258, $\mathrm{N}$ 4.2774). MS (\%) $\mathrm{M}^{+}$at $m / z 327$ (22), 241 (23), 185 (22), $175(13), 157$ (77), $128(49), 96(28)$ and $69(100) \cdot \mathrm{vcm}^{-1}$ (KBr) 3270, 2910, 1640, 1600, 1490, 1380, 1260, 1125, 1000, 920 and $805 .{ }^{1} \mathrm{H}$ NMR $\left(\mathrm{CDCl}_{3}\right) \delta 0.90(3 \mathrm{H}, \mathrm{t}, J=6.0 \mathrm{~Hz}$, $\left.-\mathrm{CH}_{2}-\mathrm{CH}_{3}\right), 1.16-1.56\left[12 \mathrm{H}\right.$, bs, $-\mathrm{NH}-\mathrm{CH}_{2}-\left(\mathrm{CH}_{2}\right)_{3}$ and $\left.\mathrm{C}-\left(\mathrm{CH}_{3}\right)_{2}\right], 1.80\left(2 \mathrm{H}, \mathrm{t}, J=6.0 \mathrm{~Hz}, \mathrm{Ar}-\mathrm{CH}_{2}-\mathrm{CH}_{2}\right), 2.72$ $\left(2 \mathrm{H}, \overline{\mathrm{t}}, J=6.0 \mathrm{~Hz}, \mathrm{Ar}-\mathrm{CH}_{2}-\mathrm{CH}_{2}\right), 3.34(2 \mathrm{H}, \mathrm{m}$, $\left.-\mathrm{N}-\left(\mathrm{CH}_{2}\right)\right), 5.94(1 \mathrm{H}, \mathrm{d}, J=15.0 \mathrm{~Hz},-\mathrm{CH}=\mathrm{CH}-\mathrm{CO})$, 6.52-6.82 and $6.90-7.66(6 \mathrm{H}, \mathrm{m}$, olefinic and $\mathrm{Ar}-\overline{\mathrm{H}})$.

Preparation of 3-(3,4-methylenedioxy phenyl)-2E-propenoic acid (6). To $\mathbf{1 h}(4.5 \mathrm{~g}, 30 \mathrm{mmol})$ in pyridine $(25 \mathrm{~mL})$ and piperidine $(1 \mathrm{~mL})$ was added malonic acid $(3.7 \mathrm{~g}, 36 \mathrm{mmol}$ ) and contents stirred for $24 \mathrm{~h}$, followed by heating on water bath for $6 \mathrm{~h}$. The contents were cooled, poured in ice-cold water, acidified with $2 \mathrm{~N}$ $\mathrm{HCl}$. The resulting precipitate filtered, washed with water and air dried to give $6(6.2 \mathrm{~g}, 95 \%)$, crystallised from ethyl acetate: $n$-hexane (9:1), mp. $244-646^{\circ} \mathrm{C}$ (lit. $\left.\mathrm{mp} 247^{\circ} \mathrm{C}\right) .{ }^{35}$

Preparation of 3-(3,4-methylenedioxy phenyl)-2E-propenoic acid piperidine amide (32). Compound 6 (2.1 g, $11 \mathrm{mmol})$ was condensed with piperidine $(1.2 \mathrm{~mL})$ as described for 8 to yield $32(2.80 \mathrm{~g}, 91 \%), \mathrm{mp} 89^{\circ} \mathrm{C}$ (analysed for $\mathrm{C}_{15} \mathrm{H}_{17} \mathrm{NO}_{3}$; found $\mathrm{C} 69.4901, \mathrm{H} 6.6089$, N 5.4071; calcd C 69.4804, H 6.6078, N 5.4017) MS (\%) $\mathrm{M}^{+}$at $m / z 259$ (4), 147 (21), 111 (100) and 84 (29). $\mathrm{vcm}^{-1}(\mathrm{KBr}) 2940,1642,1588,1494,1436,1350,1298$, 1250, 1216, 1100, 1018, 972 and 808. ${ }^{1} \mathrm{H}$ NMR $\left(\mathrm{CDCl}_{3}\right)$ $\delta 1.64\left(6 \mathrm{H}, \quad\right.$ bs, $\left.\mathrm{N}-\mathrm{C}-\left(\mathrm{CH}_{2}\right)_{3}\right), \quad 3.60 \quad(4 \mathrm{H}, \quad$ bs, $\left.-\mathrm{N}-\left(\mathrm{CH}_{2}\right)_{2}\right), 5.94\left(2 \mathrm{H}, \mathrm{s},-\mathrm{OCH}_{2} \mathrm{O}-\right), 6.70(1 \mathrm{H}, \mathrm{d}$, $J=15.0 \mathrm{~Hz}, \mathrm{CH}=\mathrm{CH}-\mathrm{CO}), 6.76(1 \mathrm{H}, \mathrm{d}, J=8.5 \mathrm{~Hz}$, $\mathrm{Ar}-\mathrm{H}), 6.98(1 \mathrm{H}, \overline{\mathrm{d}}, J=8.5 \mathrm{~Hz}, \mathrm{Ar}-\mathrm{H}), 7.02(1 \mathrm{H}, \mathrm{s}$, $\mathrm{Ar}-\mathrm{H})$ and $7.52(1 \mathrm{H}, \mathrm{d}, J=15.0 \mathrm{~Hz}, \mathrm{C} \underline{\mathrm{H}}=\mathrm{CH}-\mathrm{CO})$.

Preparation of 3-(3,4-methylenedioxy phenyl)-2E-propenoic acid pyrrolidine amide (33). Compound 6 (2.0 g, $10 \mathrm{mmol})$ was condensed with pyrrolidine $(1.0 \mathrm{~mL})$ as described for 8 to yield $33(2.4 \mathrm{~g}, 90 \%), \mathrm{mp} 146^{\circ} \mathrm{C}$ (analysed for $\mathrm{C}_{14} \mathrm{H}_{15} \mathrm{NO}_{3}$; found $\mathrm{C} 68.5603$, H 6.1644, $\mathrm{N}$ 5.7133; calcd C 68.5569, H 6.1638, N 5.7106). MS $(\%) \mathrm{M}^{+}$at $m / z 245$ (15) 174 (32) 147 (9) 98 (30) and 70 (100). vcm ${ }^{-1}(\mathrm{KBr}) \quad 2960,1646,1594,1496,1454$, $1414,1354,1320,1278,1242,1198,1018,992,928$ and 826. ${ }^{1} \mathrm{H}$ NMR $\left(\mathrm{CDCl}_{3}\right) \delta 1.92\left(4 \mathrm{H}, \mathrm{bs}, \mathrm{N}-\mathrm{C}-\left(\mathrm{CH}_{2}\right)_{2}\right)$, $3.56\left(4 \mathrm{H}, \mathrm{m},-\mathrm{N}-\left(\mathrm{CH}_{2}\right)_{2}\right), 5.96\left(2 \mathrm{H}, \mathrm{s},-\mathrm{OCH}_{2} \mathrm{O}-\right)$, $6.50(1 \mathrm{H}, \mathrm{d}, J=15.0 \mathrm{~Hz}, \mathrm{CH}=\mathrm{CH}-\mathrm{CO}), 6.78(1 \mathrm{H}, \mathrm{d}$, $J=8.5 \mathrm{~Hz}$, Ar-H), $6.97(1 \mathrm{H}, \mathrm{d}, J=8.5 \mathrm{~Hz}, \mathrm{Ar}-\mathrm{H}), 7.00$ $(1 \mathrm{H}, \mathrm{s}, \mathrm{Ar}-\mathrm{H})$ and $7.56(1 \mathrm{H}, \mathrm{d}, J=15.0 \mathrm{~Hz}, \mathrm{CH}=$ $\mathrm{CH}-\mathrm{CO})$.
Preparation of 3-[(2H)-2,2-dimethyl-3,4-dihydrobenzopyran-6yll-2E-propenoic acid (7). Compound 7 was prepared from $1 \mathrm{~g}(6.0 \mathrm{~g}, 32 \mathrm{mmol})$ and malonic acid $(4.2 \mathrm{~g}$, $40 \mathrm{mmol}$ ) as described for 6 to give crystalline compound $7^{36}(6.7 \mathrm{~g}, 90 \%), \mathrm{mp} 188^{\circ} \mathrm{C}$ analysed for $\mathrm{C}_{14} \mathrm{H}_{16} \mathrm{O}_{3}$, MS (\%) $\mathrm{M}^{+}$at $m / z 232$ (93), 215 (13), 188 (6), $176(100)$ and $131(20) . \mathrm{vcm}^{-1}(\mathrm{KBr}) 2964,1674$, $1609,1574,1494,1430,1386,1370,1304,1286,1260$, $1234,1150,932$ and $820 .{ }^{1} \mathrm{H}$ NMR $\left(\mathrm{CDCl}_{3}\right) \delta 1.32(6 \mathrm{Hs}$, $\left.-\mathrm{C}\left(\mathrm{CH}_{3}\right)_{2}\right), 1.82\left(2 \mathrm{H}, \mathrm{t}, J=7.0 \mathrm{~Hz}, \mathrm{Ar}-\mathrm{CH}_{2}-\mathrm{CH}_{2}\right), 2.74$ $\left(2 \mathrm{H}, \quad \mathrm{t}, \quad J=7.0 \mathrm{~Hz}, \quad \mathrm{Ar}-\mathrm{CH}_{2}-\mathrm{CH}_{2}\right), 6.72(1 \mathrm{H}, \mathrm{d}$, $J=15.0 \mathrm{~Hz}, \mathrm{CH}=\mathrm{CH}-\mathrm{CO}), 6.80(1 \mathrm{H}, \mathrm{d}, J=8.5 \mathrm{~Hz}$, $\mathrm{Ar}-\mathrm{H}), 7.24(1 \mathrm{H}, \overline{\mathrm{s}}, \mathrm{Ar}-\mathrm{H}), 7.28(1 \mathrm{H}, \mathrm{d}, J=8.5 \mathrm{~Hz}$, $\mathrm{Ar}-\mathrm{H})$ and $7.68(1 \mathrm{H}, \mathrm{d}, J=15.0 \mathrm{~Hz},-\mathrm{CH}=\mathrm{CH}-\mathrm{CO})$.

Preparation of 3-I(2H)-2,2-dimethyl-3,4-dihydro-benzopyran-6yll-2E-propenoic acid piperidine amide (34). Compound $7(0.93 \mathrm{~g}, 4 \mathrm{mmol})$ was condensed with piperidine $(0.6 \mathrm{~mL})$ as described for 8 to give $\mathbf{3 4}(1.10 \mathrm{~g}$, $92 \%$ ) , mp $122^{\circ} \mathrm{C}$ (analysed for $\mathrm{C}_{19} \mathrm{H}_{25} \mathrm{NO}_{2}$; found $\mathrm{C}$ 76.2221, H 8.4160, N 4.6802; calcd C 76.2191, H 8.4156, N 4.6781) MS (\%) M at $m / z 299$ (100), 214 (93), 187 (31), 158 (60) 84 (61) and $69(30) \cdot \mathrm{vcm}^{-1}(\mathrm{KBr}) 2932$, $1640,1598,1578,1494,1434,1382,1368,1270,1244$, $1232,1214,1110,1010,982$ and $830 .{ }^{1} \mathrm{H}$ NMR $\left(\mathrm{CDCl}_{3}\right)$ $\delta: 1.23\left(6 \mathrm{H}, \mathrm{s},-\mathrm{C}\left(\mathrm{CH}_{3}\right)_{2}\right), 1.56\left(6 \mathrm{H}, \mathrm{bs}, \mathrm{N}-\mathrm{C}-\left(\mathrm{CH}_{2}\right)_{3}\right)$, $1.72\left(2 \mathrm{H}, \mathrm{t}, J=6.5 \mathrm{~Hz}, \mathrm{Ar}-\mathrm{CH}_{2}-\mathrm{CH}_{2}\right), 2.72(2 \mathrm{H}, \mathrm{t}$, $\left.J=6.5 \mathrm{~Hz}, \mathrm{Ar}-\mathrm{CH}_{2}-\mathrm{CH}_{2}\right), 3.50\left(4 \mathrm{H}, \mathrm{m}, \mathrm{NH}-\left(\mathrm{CH}_{2}\right)_{2}\right)$, $6.66(1 \mathrm{H}, \mathrm{d}, J=\overline{15} .0 \mathrm{~Hz}, \mathrm{CH}=\mathrm{CH}-\mathrm{CO}), 6.62(1 \overline{\mathrm{H}}, \mathrm{d}$, $J=8.5 \mathrm{~Hz}, \mathrm{Ar}-\mathrm{H}), 7.06-7.24(\overline{2 \mathrm{H}}, \mathrm{m}, 2 \times \mathrm{Ar}-\mathrm{H})$ and $7.43(1 \mathrm{H}, \mathrm{d}, J=15.0 \mathrm{~Hz},-\mathrm{CH}=\mathrm{CH}-\mathrm{CO})$.

Preparation of 3-[(2H)-2,2-dimethyl-3,4-dihydrobenzopyran-6yl]-2E-propenoic acid isopropyl amide (35). Compound $7(1.2 \mathrm{~g}, 5 \mathrm{mmol})$ was condensed with isopropyl amine $(0.7 \mathrm{~mL})$ by the method as described for 8 to give $35(1.24 \mathrm{~g}, 91 \%), \mathrm{mp} 89^{\circ} \mathrm{C}$ (analysed for $\mathrm{C}_{17}$ $\mathrm{H}_{23} \mathrm{NO}_{2}$; found $\mathrm{C} 74.6898$, H 8.4823, N 5.1255; calcd C 74.6900, H 8.4816, N 5.1236); MS (\%) $\mathrm{M}^{+}$at $m / z 273$ (100), $215(61), 188(58), 159(51)$ and $58(48) . \mathrm{vcm}^{-1}(\mathrm{KBr})$ $3260,2968,1654,1612,1580,1496,1420,1384,1370$, $1304,1236,1200,1152,1112,1000,920$ and $874 .{ }^{1} \mathrm{H}$ NMR $\left(\mathrm{CDCl}_{3}\right) \delta 1.20\left(6 \mathrm{H}, \mathrm{d}, J=6.5 \mathrm{~Hz},-\mathrm{C}\left(\mathrm{CH}_{3}\right)_{2}\right)$, $1.33\left(6 \mathrm{H}, \mathrm{s},\left(\mathrm{CH}_{3}\right)_{2}\right), 1.76\left(2 \mathrm{H}, \mathrm{t}, J=6.50 \mathrm{~Hz}, \mathrm{Ar}-\mathrm{CH}_{2}\right.$ $\left.-\mathrm{CH}_{2}\right), 2.70\left(2 \mathrm{H}, \mathrm{t}, J=6.5 \mathrm{~Hz}, \mathrm{Ar}-\mathrm{CH}_{2}\right), 4.13(1 \mathrm{H}, \mathrm{m}$, $\mathrm{CH}-\mathrm{N}), 6.13(1 \mathrm{H}, \mathrm{d}, J=15.0 \mathrm{~Hz}, \mathrm{CH}=\mathrm{CH}-\mathrm{CO}), 6.63$ $(1 \mathrm{H}, \mathrm{d}, J=8.5 \mathrm{~Hz}, \mathrm{Ar}-\mathrm{H}), 6.95-7.23(2 \overline{\mathrm{H}}, \mathrm{m}, \mathrm{Ar}-\mathrm{H})$ and $7.43(1 \mathrm{H}, \mathrm{d}, J=15.0 \mathrm{~Hz},-\mathrm{CH}=\mathrm{CH}-\mathrm{CO})$.

Preparation of 3-[(2H)-2,2-dimethyl-3,4-dihydrobenzopyran-6yl-2E- propenoic acid $n$-butylamide (36). Compound $7(1.2 \mathrm{~g}, 5 \mathrm{mmol})$ was condensed with $n$-butylamine $(0.6 \mathrm{~mL})$ by the method as described for 8 to give 36 $\left(1.29 \mathrm{~g}, 90 \%\right.$ ), $\mathrm{mp} 86^{\circ} \mathrm{C}$ (analysed for $\mathrm{C}_{18} \mathrm{H}_{25} \mathrm{NO}_{2}$; found C 75.2301, H 8.7677, N 4.8771; calcd C 75.2253, H 8.7673, $\mathrm{N} 4.8736)$. MS (\%) $\mathrm{M}^{+}$at $m / z 287$ (100), 242 (79), 214 (79), 187 (21), 170 (12), 158 (60) 130 (30) and 72 (14). $\mathrm{vcm}^{-1}$ (KBr) 3200, 2932, 1648, 1616, 1580, 1544, 1450, $1424,1384,1370,1308,1264,1236,1152,968$ and $852 .{ }^{1} \mathrm{H}$ NMR $\left(\mathrm{CDCl}_{3}\right) \delta 0.92\left(3 \mathrm{H}, \mathrm{t}, J=6.5 \mathrm{~Hz},-\mathrm{CH}_{2}-\mathrm{CH}_{3}\right)$, $1.33\left(6 \mathrm{H}, \mathrm{s},-\mathrm{C}\left(\mathrm{CH}_{3}\right)_{2}\right), 1.49\left(4 \mathrm{H}, \mathrm{m},-\mathrm{C}-\left(\mathrm{CH}_{2}\right)_{2}\right), 1.79$ $\left(2 \mathrm{H}, \mathrm{t}, J=6.5 \mathrm{~Hz}, \mathrm{Ar}-\mathrm{CH}_{2}-\mathrm{CH}_{2}\right), 2.74(2 \mathrm{H}, \mathrm{t}, J=6.5 \mathrm{~Hz}$, $\left.\mathrm{Ar}-\mathrm{CH}_{2}-\mathrm{CH}_{2}\right), 3.34\left(2 \mathrm{H}, \mathrm{m}, \mathrm{NH}-\mathrm{CH}_{2}\right), 6.38(1 \mathrm{H}, \mathrm{d}$, 
$J=15.0 \mathrm{~Hz}, \mathrm{CH}=\mathrm{CH}-\mathrm{CO}), 6.66(1 \mathrm{H}, \mathrm{d}, J=8.5 \mathrm{~Hz}, \mathrm{Ar}-$ $\mathrm{H}), \quad 7.09-7.42(2 \overline{\mathrm{H}}, \mathrm{m}, \mathrm{Ar}-\mathrm{H})$ and $7.67(1 \mathrm{H}, \mathrm{d}$, $J=15.0 \mathrm{~Hz},-\mathrm{CH}=\mathrm{CH}-\mathrm{CO})$.

Preparation of 3-[(2H)-2,2-dimethyl-3,4-dihydrobenzopyran-6yl]-2 $E$-propenoic acid $n$-hexylamide (37). Compound 7 (0.93 g, $4 \mathrm{mmol})$ was condensed with hexylamine $(0.5 \mathrm{~mL})$ as described for 8 to give $37(1.15 \mathrm{~g}, 91 \%), \mathrm{mp}$ $71^{\circ} \mathrm{C}$ (analysed for $\mathrm{C}_{20} \mathrm{H}_{29} \mathrm{NO}_{2}$; found $\mathrm{C} 76.1600, \mathrm{H}$ 9.2666, N 4.4443; calcd C 76.1505, H 9.2657, N 4.4402). MS (\%) $\mathrm{M}^{+}$at $m / z 315$ (82), 258 (16), 215 (92), 187 (22), $173(100)$ and $99(19) . \mathrm{vcm}^{-1}(\mathrm{KBr}) 3190,2900,1654,1608$, 1573, 1540, 1494, 1283, 1381, 1367, 1306, 1238, 1214, $1154,1120,928$ and $818 .{ }^{1} \mathrm{H}$ NMR $\left(\mathrm{CDCl}_{3}\right) \delta: 0.89(3 \mathrm{H}, \mathrm{d}$, $\left.J=6.5 \mathrm{~Hz},-\mathrm{CH}_{3}\right), 1.30\left(6 \mathrm{H}, \mathrm{s},-\mathrm{C}\left(\mathrm{CH}_{3}\right)_{2}\right), 1.33(8 \mathrm{H}, \mathrm{m}$, $\left.-\mathrm{C}\left(\mathrm{CH}_{2}\right)_{4}-\mathrm{CH}_{3}\right), 1.76\left(2 \mathrm{H}, \mathrm{t}, J=6.0 \mathrm{~Hz}, \mathrm{Ar}-\mathrm{CH}_{2}-\mathrm{CH}_{2}\right)$, $\left.2.73 \overline{(2} \mathrm{H}, \mathrm{t}, J=6.0 \mathrm{~Hz}, \mathrm{Ar}-\mathrm{CH}_{2}\right), 3.33\left(2 \mathrm{H}, \mathrm{m}, \mathrm{NH}-\overline{\mathrm{CH}}_{2}\right)$ $6.23(1 \mathrm{H}, \mathrm{d}, J=15.0 \mathrm{~Hz}, \mathrm{CH}=\mathrm{CH}-\mathrm{CO}), 6.70(1 \mathrm{H}, \mathrm{d}$, $J=8.5 \mathrm{~Hz}, \mathrm{Ar}-\mathrm{H}), 7.10-7.33(2 \mathrm{H}, \mathrm{m}, \mathrm{Ar}-\mathrm{H})$, and 7.54 $(1 \mathrm{H}, \mathrm{d}, J=15.0 \mathrm{~Hz},-\mathrm{CH}=\mathrm{CH}-\mathrm{CO})$.

\section{Biology}

Chemicals. Chemicals and cell culture medium were purchased from the following sources: NADPH from Sigma Chemie, München, FRg; 7-methoxycoumarin (MOC) from Aldrich Chemie, Steinheim, FRg and purified as described earlier. ${ }^{21}$ The sources of piperine and other chemicals are described elsewhere. ${ }^{2,6}$ All other chemicals used were of analytical grade and available locally.

Animals and treatment. Adult male albino Charles Foster rats $(200 \pm 20 \mathrm{~g}$, body $\mathrm{wt})$ and male Swiss albino mice $(25 \pm 2 \mathrm{~g}$, body wt) used were bred in the animal house of this institute. The animals were maintained on standard commercial pellet food (Hindustan Lever Ltd., Bombay) and water ad libitum. Rats were treated with $3 \mathrm{MC}$ and $\mathrm{PB}$ for inducibility of CYP activities as described earlier. ${ }^{2}$

Preparation of microsomes. Liver whole homogenate $(25 \%, \mathrm{w} / \mathrm{v})$ in $0.25 \mathrm{M}$ sucrose was prepared from overnight fasted rats and centrifuged at $10,000 \mathrm{~g}$ for $15 \mathrm{~min}$. The post-mitochondrial supernatant was recentrifuged and pellet discarded each time. Microsomal fraction was prepared from the supernatant by $\mathrm{Ca}^{++}$-precipitation. ${ }^{37}$ The pellet was resuspended in $0.25 \mathrm{M}$ sucrose/ $1 \mathrm{mM}$ phosphate buffer, $\mathrm{pH} 7.6$ so as to obtain protein $30-40 \mathrm{mg} / \mathrm{mL}$. The preparation was stored in small portions at $-70^{\circ} \mathrm{C}$.

Assay of hepatic microsomal 7-methoxycoumarin $O$-demethylase (MOCD) and arylhydrocarbon hydroxylase (AHH) activities. MOCD activity was determined according to Reen et al. ${ }^{21}$ Briefly, the assay system in a total volume of $1 \mathrm{~mL}$ contained $40 \mathrm{mM}$ Tris- $\mathrm{HCl}$ buffer $\mathrm{pH} 7.6,5 \mathrm{mM} \mathrm{MgCl}_{2}, 0.25 \mathrm{mg}$ NADPH, $0.1-0.2 \mathrm{mg}$ microsomal protein and piperine or test compound in $10 \mu \mathrm{L}$ of $50 \%$ methanol. The reaction was started with $0.4 \mathrm{mM} 7$-methoxycoumarin in $10 \mu \mathrm{L}$ of $50 \%$ methanol. The assay system was incubated for $10 \mathrm{~min}$ at $37^{\circ} \mathrm{C}$ in a constant shaking water bath. The reaction was terminated with $75 \mu \mathrm{L}$ of $15 \%$ cold TCA (w/v). The product 7-OH-coumarin was extracted and measured fluorometrically at $396 \mathrm{~nm}$ excitation and $520 \mathrm{~nm}$ emission.

The activity of arylhydrocarbonhydroxylase $(\mathrm{AHH})$ was measured according to Wiebel et al. ${ }^{38}$ Briefly, the reaction mixture in a total volume of $1 \mathrm{~mL}$ contained $50 \mathrm{mM}$ Tris- $\mathrm{HCl}$ buffer, $\mathrm{pH} 7.6,3 \mathrm{mM} \mathrm{MgCl}_{2}, 0.6 \mathrm{mM}$ NADPH and 0.5 to $2.5 \mathrm{mg}$ microsomal protein. Piperine or test compound was added in $10 \mu \mathrm{L}$ of $50 \%$ methanol. The reaction was started under subdued light with $0.1 \mathrm{mM}$ benzo (a) pyrene in $20 \mu \mathrm{L}$ of $50 \%$ methanol and incubated at $37^{\circ} \mathrm{C}$ for $30 \mathrm{~min}$ in a shaking water bath. The reaction was terminated and the relative fluorescence of the aqueous phase was measured at $396 \mathrm{~nm}$ excitation and $520 \mathrm{~nm}$ emission using 3-OHbenzo(a)pyrene as reference standard.

Sleeping time. The hexobarbital induced sleeping time was determined as the time required for the mice to regain their rightening reflex. ${ }^{2}$ The control animals received only the vehicle.

Cell culture and treatment. H4IIEC $3 / \mathrm{G}$ - cells used in the present study are the descendants of rat Reuber hepatoma. Their source, growth characteristics and incubation conditions are described earlier. ${ }^{4,39}$ Cells were seeded at a density of $1 \times 10^{6}$ cells per $90 \mathrm{~mm}$ plastic dishes in DMEM containing fetal calf serum and antibiotics and allowed to grow for $48 \mathrm{~h}$. Cultures were exposed for $24 \mathrm{~h}$ to fresh medium containing test compound delivered in $15 \mu \mathrm{L}$ DMSO. Control plates received only the vehicle. Cells were washed with phosphate buffer saline (PBS) and harvested in $1 \mathrm{~mL}$ PBS and centrifuged. The pellet was stored in liquid nitrogen and used for assay of monooxygenase activities after suspension in $50 \mathrm{mM}$ Tris- $\mathrm{HCl}$, pH 7.4.

\section{References}

1. Warrier, P. K. Indian Spices 1981, 18, 32.

2. Atal, C. K.; Dubey, R. K.; Singh, J. J. Pharm. Exptl. Therap. 1985, 232, 258.

3. Singh, J.; Dubey, R. K.; Atal, C. K. J. Pharm. Exptl. Therap. 1986, 236, 488.

4. Singh, J.; Reen, R. K.; Wiebel, F. J. Cancer Letters 1994, 86, 195 .

5. Reen, R. K.; Singh, J. Ind. J. Exptl. Biol. 1991, 29, 568.

6. Reen, R. K.; Jamwal, D. S.; Taneja, S. C.; Koul, J. L.; Dubey, R. K.; Wiebel, F. J.; Singh, J. Biochem. Pharmaco. 1993, 46, 229.

7. Reen, R. K.; Roesch, S. F.; Kiefer, F.; Wiebel, F. J.; Singh, J. Biochem. Biophys. Res. Commun. 1996, 218, 562.

8. Bano, G.; Amla, V.; Raina, R. K.; Zutshi, U.; Chopra, C. L. Planta Medica 1987, 53, 568.

9. Allameh, A.; Saxena, M.; Biswas, G.; Raj, H. G.; Singh, J.; Srivastava, N. Cancer Letters 1991, 61, 195.

10. Reen, R. K.; Wiebel, F. J.; Singh, J. J. Ethnopharmacol 1997, 58, 165 .

11. Piyachaturawat, P.; Glinsukon, T.; Toskulkao, C. Toxicol. Lett. 1983, 16, 351.

12. Spitteller, G. Agnew. Chem. Int. (English edition) 1985, 24, 451.

13. Murray, M.; Reidy, G. F. Pharmacol. Rev. 1990, 42, 85. 
14. Oritz de Montellano, P. R.; Reich, N. O. Inhibition of cytochrome P450 enzymes In Cytochrome P450, Structure, Mechanism and Biochemistry; Oritz de Montellano, P. R., Ed.; Plenum Press: New York, 1986; pp 273-314.

15. Halpert, J. R.; Guengerich, F. P.; Bend, J. R.; Correia, M. A. Toxicol. App. Pharmacol 1994, 125, 163.

16. Cole, P. A.; Robinson, C. H. J. Med. Chem. 1990, 33, 2933.

17. Geng-Tao, L. Drug Met. Review 1991, 23, 439.

18. Hodgson, E.; Philpot, R. W. Drug Met. Rev. 1974, 3, 231. 19. Dalvi, R. R.; Dalvi, P. S. Drug and Chem. Toxicol. 1991, 14, 219.

20. Nebert, D. W. Critical Reviews in Toxicol. 1989, 20, 137.

21. Reen, R. K.; Ramakanth, S.; Wiebel, F. J.; Jain, M. P.; Singh, J. Analyt. Biochem. 1991, 194, 243.

22. Conney, A. H. Pharamacol. Rev. 1967, 19, 317.

23. Reddy, M. P.; Rao, G. S. K. Synthesis 1980, 10, 815.

24. Barik, B. R.; Kundu, A. B.; Dey, A. K. Phytochemistry 1987, 26, 2126.

25. Banerji, A.; Ghosal, T.; Acharyya, A. K. Ind. J. Chem. 1984, $23 B, 546$.

26. Garqiulo, D.; Ikemato, N.; Odingo, J.; Bozhkova, N.; Iwashita, T.; Berova, N.; Naganishi, K. J. Am. Chem. Soc. 1994, 116, 3760 .

27. Dictionary of Natural Products, Chapman and Hall, 1994, 4, 3920 .

28. Atal, C. K.; Dhar, K. L.; Gupta, O. P.; Gupta, S. C.; Saxena, B. P.; Koul, O.; Gupta, S. C. Ind. J. Exptl. Biol. 1977, 15, 1230. 29. Dictionary of Natural Products, Chapman and Hall, 1994, 4, 3920 .

30. Burgi von, C.; Liu, G.; Ruedi, P. Helv. Chim. Acta. 1993, 16,1901 .
31. Inatoni, R.; Nakatani, N.; Fuwa, H. Agri. Biol. Chem. 1981, 45, 667.

32. Boulware, R. T.; Stermitz, F. R. J. Nat. Prod. 1981, 44, 200.

33. Banwell, M. G.; Lambert, J. N.; Corbet, M.; Greenwood, R. J.; Gulbis, J. M.; Mackay, M. F. J. Chem. Soc. Perkin. Trans. 1 1992, 11, 1415.

34. Fatope, M. O.; Abraham, D. G. J. Med. Chem. 1987, 30, 1973.

35. Dictionary of Natural Products, Chapman and Hall, 1994, 4, 3921

36. Fujimura, H.; Sawada, T.; Kitagawa, I. Chem. Abstr. 1984, 104, 33867j.

37. Kamath, S. A.; Rubin, E. Biochem. Biophys. Res. Commun. 1972, 49, 52.

38. Wiebel, F. J.; Brown, S.; Waters, H. L.; Selkirik, J. K. Arch. Toxicol. 1977, 39, 133.

39. Singh, J.; Reen, R. K. Current Science 1994, 66, 365.

40. Hennessy, D. J. J. Agr. Food Chem. 1965, 13, 218.

41. Eclombe, C. R.; Bridges, J. W.; Cray, T. J. B.; NimmoSmith, R. H.; Netter, K. G. Biochem. Pharmacol. 1975, 24 , 1427.

42. Dickens, M.; Bridges, J. W.; Eclombe, C. R.; Netter, K. J. Biochem. Biophys. Res. Commun. 1978, 80, 89

43. Cook, J. C.; Hodgson, E. Toxicol. App. Pharmacol. 1983, 68, 131.

44. Murray, M.; Wilkinson, C. F.; Marcus, C.; Dube, C. E. Mol. Pharmacol. 1983, 24, 129.

45. Anders, M. Annu. Rev. Pharmacol. 1971, 11, 37.

46. Philpot, R. M.; Hodgson, E. Mol. Pharmacol. 1972, 8, 204. 47. Jamwal, D. S.; Singh, J. J. Biochem. Toxicol. 1993, 8, 167. 